\title{
Mecmûa-i İber-i İntibâh ve Osmanlı Popüler Bilim Dergileri Arasında İlk Polemikler
}

\section{The Mecmûa-i İber-i İntibâh and the Early Polemics Among Ottoman Popular Science Journals}

\author{
Bilal Yurtoğlu ${ }^{1}$
}

'Doç. Dr., Kastamonu Üniversitesi, Fen Edebiyat Fakültesi, Felsefe Bölümü, Kastamonu, Türkiye

\section{ORCID: B.Y. 0000-0003-2534-6334}

Sorumlu yazar/Corresponding author: Bilal Yurtoğlu,

Kastamonu Üniversitesi

Fen Edebiyat Fakültesi, Felsefe Bölümü

Kastamonu, Türkiye

E-posta/E-mail: byurtoglu@kastamonu.edu.tr

Başvuru/Submitted: 21.09 .2021

Kabul/Accepted: 20.10 .2021

Atıf/Citation: Yurtoğlu, Bilal. "Mecmûa-i iber-i Intibah ve Osmanlı Popüler Bilim Dergileri Arasında Illk Polemikler." Osmanlı Bilimi Araştırmaları 23, 1 (2022): 103-125. https://doi.org/10.26650/oba.998466

\section{öz}

Aralık 1862'de Cemiyet-i Kitâbet tarafından yayınlanmaya başlanan Mecmûa-i Iber-i Intibâh Osmanlı́nın ikinci popüler bilim dergisidir. Dergi, Haziran 1864 yılındaki sekizinci sayıdan sonra yayınına ara vermiş, Ekim 1865'ten itibaren adını Mecmûa-i Ibretnümâ olarak değiştirerek dokuzuncu sayıdan devamla bu kez aylık olarak düzenli şekilde tekrar yayınlanmaya başlamıştır. On altıncı ve son sayısı Mayıs 1866 tarihlidir. Eğitimin önemini vurgulayan dergi, amacını okul çocuklarının okuyup faydalanacağı bir eser olmak şeklinde açıklamaktadır. İçerdiği yazılardan, söz konusu topluluğun ve dergisinin geleneksel bir kültür anlayışına sahip olduğu anlaşılmaktadır. Derginin, ilk Osmanlı popüler bilim dergisi olan Mecmûa-i Fünûn ile bilimsel olmayan sert polemiklere girdiği görülmektedir. Dergideki bazı yazıların Mukaddime'den aktarmalarla oluşturulması İbn Haldun'un o dönem Osmanlı kültür yaşamındaki etkisini göstermesi bakımından önemlidir. Vidinli Tevfik'in Bahaeddin el-Âmulî́nin Arapça Hülâsatu'I-Hisâb adlı aritmetiğe ilişkin eserinin Türkçe açıklamalar da içeren çevirisine başladığı gösteren tefrikası dâhil olmak üzere, o dönemde yayınlanmış ancak ilgili bibliyografyalarda kaydı bulunmayan bazı bilim tarihi kitapları hakkında verdiği bilgiler, derginin bilim ve kültür tarihimiz açısından önemli yönleri olarak değerlendirilebilir.

Anahtar sözcükler: Mecmûa-i İber-i Intibâh, Mecmûa-i İbretnümâ, Cemiyet-i Kitâbet, Mecmûa-i Fünûn, İbn Haldun, Bahaeddin el-Âmulî, Vidinli Tevfik

\section{ABSTRACT}

First published in December 1862 by the Cemiyet-i Kitâbet, the Mecmûa-i iber-i Intibâh was the second most popular Ottoman science journal. The journal ceased publication after its $8^{\text {th }}$ issue in June 1864. Its name was changed to Mecmûa-i ibretnümâ from its $9^{\text {th }}$ issue (October 1865) onward, and thereafter, it became a monthly journal. Its $16^{\text {th }}$ and final issue was dated May 1866. Emphasizing the importance of education, the journal's aim was to provide reading materials for school children. Its content reflects the traditional 
understanding of culture and society. It went into non-scientific polemics with the Mecmûa-i Fünûn, the first popular science magazine of the Ottoman Empire. Journal's articles quoting from the Mukaddime witness the influence of Ibn Khaldun on Ottoman cultural life of the time. The journal further informs regarding the Turkish translation by Vidinli Tevfik from Bahaeddin el-Âmûlî's arithmetical book, Hülâsatü'l-Hisâb, and some history of science books of the time, which were not recorded in bibliographies. These pieces of information are crucial because they attest to the unknown aspects of Turkish scientific and cultural history.

Keywords: Mecmûa-i Iber-i Intibâh, Mecmûa-i Ibretnümâ, Cemiyet-i Kitâbet, Mecmûa-i Fünûn, Ibn Khaldun, Bahaeddin al-Âmûlî, Vidinli Tevfik 


\section{Giriş}

1862 yılı sonu 1863 yılı başına gelindiğinde (Receb 1279) İstanbul'da altı Türkçe gazete basıldı̆̆ı görülmektedir. Bunlardan Takvîm-i Vekâyi ve Cerîde-i Askeriye resmî; önceleri Cerîde-i Havâdis daha sonra R̂uznâme-i Cerîde-i Havâdis adıla yayımlanan gazete yarı resmî; Tercümân-ı Ahvâl ve Tasvîr-i Efkâr ise gayr-i resmî gazetelerdir. Tek bilim dergisi, Cemiyet-i İlmiye-i Osmâniye'nin eseri olarak ilk sayısı Haziran 1862 tarihinde çıkan ve aylık yayımlanan Mecmûa-i Fünûn'dur. Aralık/Ocak ayına doğru Cemiyet-i Kitâbet adıyla kurulan başka bir topluluk tarafından Mecmûa-i İber-i Intibâh adında yeni bir Türkçe dergi daha çıkarılmaya başlanır. İki ayda bir yayınlanacağı bildirilen dergi, Haziran/Temmuz 1864 (Muharrem 1281) tarihli sekizinci sayısından sonra yayınına ara verir. Yapılan bir değişiklikle Mecmûa-i İbretnümâ adını alan dergi, Ekim/Kasım 1865'te (Cemaziyelâhir 1282) yeni adıyla dokuzuncu sayıdan itibaren tekrar yayınlanmaya başlar. Derginin on altıncı ve son sayısı Mayıs/Haziran 1866 (Muharrem 1283) tarihlidir. ${ }^{1}$

Basın ve edebiyat tarihimize dair çeşitli yayınlarda adları ve yayın tarihlerinin zikredildiği görülen Cemiyet-i Kitâbet ve dergileri Mecmûa-i İber-i Intibâh ya da sonraki adıyla Mecmûa-i İbretnümâ hakkında Osmanlı modernleşme dönemine ait temel kaynak sayılabilecek eserlerde bilgi bulunmamaktadır. ${ }^{2}$ Bu makalede, kendini "maârif ve edebiyâta dâ'ir risâle" olarak niteleyen Mecmûa-i İber-i İntibâh / Mecmûa-i İbretnümâ konu edilecek ve içeriği, özellikle bilim ve kültür tarihimiz açısından incelenip tanıtılacaktır.

\section{Derginin Özellikleri}

Cemiyet-i Kitâbet' in yayın organı olarak İstanbul'da (Dersaadet/Kostantiniye) Tercümân-1 Ahvâl Matbaası'nda basılan Mecmûa-i İber-i Intibâh'ın Receb 1279'da (Aralık 1862 Ocak 1863) yayınlanan ilk sayısında dergi hakkında, Meclis-i Vâlâ mütercimlerinden Ali Haydâr ${ }^{3}$ imzalı kısa bir açıklama görülmektedir. Bu yazıda, padişahın ülkenin mâmûriyetini ve ahalinin refahını sağlayan bilgilerin ve sanayinin yayılıp artmasını istediği bildirilir. Bu amaçla Cemiyet, her türden tebaa okullarının çoğalması, çocukların terbiye ve tahsil görmeleri

1 Mecmûa-i İbretnümâ sayı 12, Ramazan 1282 (Ocak/Şubat 1866): 8-21. Mecmûa-i İbretnümâ'nın on ikinci sayısında Osmanlı matbuat tarihiyle ilgili önemli bir yazı bulunmaktadır. Makalemizin “Giriş”indeki söz konusu tarihle ilgili bilgiler bu önemli yazıdan alınmıştır.

2 Burada söz edilen eserler için bkz. Niyazi Berkes, Türkiye'de Çağdaşlaşma, haz. Ahmet Kuyaş (İstanbul: Yapı Kredi Yayınları, 2002); Ahmed Hamdi Tanpınar, 19’uncu Asır Türk Edebiyat Tarihi (İstanbul: Çağlayan Kitabevi, 2003); Hilmi Ziya Ülken, Türkiye'de Çağdaş Düşünce Tarihi (İstanbul: Ülken Yayınları, 2005).

3 Mihalıçlı Ali Haydar Bey (1836-1914), özel hocalardan Arapça ve Farsça okuduktan sonra 1850'de kâtip olarak devlette göreve başlamış Babıali, Meclis-i Tanzimat, Meclis-i Vâlâ ve Paris Sefaret kâtipliği vb. gibi görevlerin ardından amcası Mahmud Nedim Paşa'nın (1818-1883) 1871-72 ve 1872-3'teki sadaretleri sırasında daha yüksek bürokratik mevkiler elde etmiş, 1908'de emekli edilmiş, 1914'te İstanbul'da ölmüştür. Türk tiyatrosunda ilk manzum trajedi örneklerini yazmış olan Ali Haydar Bey, Cemiyet-i Kitâbet adlı derneğin kurucusudur. Mehmet Arslan, “Ali Haydar Bey Mihalıçlı,” Türk Edebiyatı İsimler Sözlüğü (TEİS), erişim tarihi: 17.08.2021, http://teis.yesevi.edu.tr/madde-detay/ali-haydar-bey-mihalicli. 
için çaba sarf etmekte ve yabancı dillerde yazılmış olup ancak okunması gereken kitap ve risalelerin tercümesine rağbet etmektedir. Ali Haydar da sırf çocuklara hizmet olması için, Türkçe ve yabancı dillerde yazılıp, ibret ve uyanıklık (intibâh) sağlayacak kısa yazıların yanı sıra tarih ve coğrafyaya dair kitap ve risalelerden alınıp tercüme edilmiş yazılardan oluşan Mecmûa-i İber-i Intibâh adlı dergiyi (risâle) Tercümân-1 Ahvâl gazetesinin matbaasında bastırarak okullara hediye edecektir. ${ }^{4}$

Derginin fiyatının beş kuruş olduğu, iki ayda bir çıkacağı ifade edilmekte, ayrıca okuyucuların yayımlanmasını istedikleri dinî ve politik olmayan yazıları söz konusu matbaaya gönderilebilecekleri belirtilmektedir. İkinci sayısının girişindeki "Mecmûanın Nizâmı" başlıklı yazıda yine dergi ve amaçları hakkında bu kez daha ayrıntılı açıklamalara yer verilmektedir. Derginin çıkarılmasındaki asıl maksatın " mekteblerde kıra' at" olduğu için, içerdiği konuların gayet sade bir dille ifade edileceği, gönderilen ve uygun görülen yazıların sahibinin imzasıyla yayınlanacağı, arzu edenlerin derginin "dâ'imî ve gayr-i dâ 'imî sûretde a 'zâlı̆̆ına" memnuniyetle kabul edilecekleri bildirilerek dergiye yazı göndermek isteyenlerin uyması gereken şartlar dokuz madde halinde sıralanmaktadır. Dinî ve politik unsurların yer almaması, devletin kurulu düzen ve kanunları aleyhinde bulunulmaması, kişilere hakaret içermemesi istenen yazılarda, edebî manzûm hikayelere, kasîde, nasihat, rubaî, ve tarihî konulara yer verileceği, ancak gazellerden uzak durulacağı belirtilmektedir. Din ve politika bakımından seviyesiz ve "efkâr-ı umûmiye"yi bozma amaçlı yazılar kabul edilmeyecek, gönderilen yazılar dergi tarafından kontrol edilip uygun görüldüğünde yayımlanacaktır. Derginin zarar ve kârı kurucusuna ait olacak, masraflar çıktıktan sonra elde edilecek kâr hayır işlerinde harcanacak ve harcamalar dergide duyurulacaktır. Son iki maddedeye göre, üyelik arzusunda olanlara, gönderdikleri yazıları (mevâdd) içeren nüshalardan ikişer adet ücretsiz verilecek ve dergiye en fazla üç mübeyyiz (müsveddeleri temize çeken kişi) dışında görevli üye kabul edilmeyecektir. ${ }^{5}$

Yedinci sayının numarasız arka kapak sayfasında, Arabî takvime uygun olarak artık aylık yayımlanacağı söylenen derginin fiyatının beşten iki kuruşa yıllık abonelik bedelinin otuzdan yirmi dört kuruşa düşürüldüğü belirtilmekte ve abonelik için önceden derginin müessisine başvurulması istenirken bu kez Tasvir-i Efkâr Matbaası'ndaki dergi görevlisi Ahmed Efendi'ye müracaat edilmesi istenmektedir. ${ }^{6}$

Dokuzuncu sayıdan itibaren derginin adı Mecmûa-i İbretnümâ olarak değiştirilmiş ve sayfa numaraları öncekilerin aksine her sayıda yeniden başlatılmıştır. Söz konusu sayının "Mukaddime"sinde, Mahmûd Celâl Bey tarafindan, olabildiğince edebî bir dille, bir süre yayımlanamayan derginin, bu tür faydalı eserleri takdir eden bazı hamiyetli kişilerin

Mecmûa-i İber-i İntibâh sayı 1 (Receb 1279 / Aralık-Ocak 1862-1863): 2-3.

Mecmûa-i İber-i İntibâh say1 2 (Şevval 1279 / Ocak-Şubat 1863): 28-30.

Mecmûa-i İber-i İntibâh say1 7 (Şevvâl 1280 / Mart-Nisan 1864). 
yardımıyla, bundan böyle yeni adıyla tekrar yayımlanacağı açıklanmıştır.7 İlk sekiz sayıdaki yazılara ve yazarlarına bakıldığında derginin ilk dönem sorumlusunun "Meclis-i Vâlâ" mütercimlerinden Ali Haydar Bey olduğu, buna karşılık derginin ad değişikliği yapılan ikinci dönemde sorumluluğun "ser-kâtib-i Meclis-i Vâlâ" olan Mahmûd Celâl Bey'e geçtiği anlaşılmaktadır. Ayrıca ilk dönem dergiyi yönetip pek çok yazısı yayımlanan Ali Haydar Bey'in, on altıncı sayıya kadar yayımlanan bu ikinci ve yeni dönemde dergide hiçbir yazısı yer almamaktadir.

Nüsha fiyatı ve yıllık abonelik ücretinin yeniden belirlenerek, ilkinin dört kuruş, ikincisinin ise kırk beş kuruş yapıldığı onuncu sayıda, derginin yayım politikaları ve içeriğine dair açıklamalar içeren "İhtâr" başlıklı bir yazı bulunmaktadır. Burada yine çok edebî bir dille, derginin çeşitli sıkıntılar nedeniyle yayımına ara vermesine rağmen bilgi pazarında yeniden revaç ve kıymet bulduğu ifade edildikten sonra, dergide eski ve yeni eserlerden alınan manzûm ve mensûr yazılara yer verileceği duyurularak, yayımlanması için dergiye yazı göndereceklerin uymaları gereken kurallar üç madde halinde açıklanmaktadır. Buna göre, dergide dinî, politik, devlet idaresi ve kanunlarına ilişkin ve kişisel işlerden söz eden yazılara yer verilmeyecektir. Nasihat türü yazılar (nesâyih), manzûm hikayeler, kasîdeler, rubaîler, yazma sanatı (fenn-i inşâ), tarih ve gazele ilişkin ustaca yazılmış yazılar ile eski yazarların uygun görülen tarihi yazıları yayımlanacaktır. Bu özelliklere uygun yazıların dergide yayımlanmasını isteyenlerin, bunları ekleri imzalı olarak Tasvîr-i Efkâr Matbaası'na göndermeleri gerekmektedir. İmzasız olan hiçbir evrak kabul edilmeyecektir. ${ }^{8}$ Sonraki tüm sayıların ilk sayfasında "Cemiyet-i Kitâbet Mevâdd-ı Nizâmnâmesi” başlığı ile üç madde halinde tekrar eden bu ifadeler, derginin daha önce karşı çıkılan ilk dönem yayım anlayışınıgazeller hariç - yeni dönemde de koruduğunu göstermektedir.

On birinci sayıda "Cemiyet-i Kitâbet" imzasıyla, derginin yayın anlayış ve uygulamaları hakkında bilgi veren "İhtâr" başlıklı son bir uyarı notu ile karşılaşılmaktadır. Burada "fünûn, maârif, tevârîh ve inşâya dâ'ir âsâr ve ebhâsı mutazammın" olarak ikinci kez çıkarılan dergide görülecek ibare ve kelime hataları iyi niyetle bildirilirse, değerlendirilip uygun görülenlerin düzeltileceği belirtilmektedir. Topluluk ayrıca, uzun tartışmalara yol açan ve amaçlarına uygun olmayan konularla uğraşmayı kabul etmeyeceğini, gazetelerde bu yönde yazılar çıkarsa umursayıp cevap vermeyeceklerini ve topluluğa gönderilmeden başka yollarla yapılan duyurulara da dergide yer verilmeyeceğini ifade etmektedir. ${ }^{9}$

\section{Derginin İçeriği}

Dergide yayımlanan yazılar, ülke ve İstanbul'a ilişkin haberler bir yana bırakılırsa, büyük ölçüde edebiyat ve tarih ile ilgilidir. Öte yandan dergide felsefe ile ilgili birkaç yazının

7 Mecmûa-i İbretnümâ sayı 9 (Cemaziyelâhir 1282 / Ekim-Kasım 1865): 2-4.

8 Mecmûa-i İbretnümâ sayı 10 (Receb 1282 / Kasım-Aralık 1865): 2-4.

9 Mecmûa-i İbretnümâ sayı 11 (Şaban 1282 / Aralık-Ocak 1865/1866): 2-3. 
yanı sıra bilim başlığı altında toplayabileceğimiz özellikle coğrafya ve matematikle ilgili önemli tefrikalar da yer almaktadır. Şimdi, belirlediğimiz bu başlıklar altında derginin içeriği hakkında bilgi verelim.

\section{Edebî Yazılar}

Edebiyatla ilgili yazılar içinde kasîde, mersiye vb. gibi hemen her sayıda sıkça rastlanan örnekler önemli yer tutmaktadır. Ayrıca birkaç sayı devam eden şiir örnekleri hatta Arap Şiirinden Seçmeler (Müntehab-1 Şi'r-i Arabî) ${ }^{10}$ başlıklı yazılara da rastlanmaktadır. Yine bu alanda, Türkçe ile ilgili bir yazı görülmezken, "Arapça'dan sonra bütün dillerin en şereflisi, en güzeli, en tatlısının Farsça olduğu müsbettir" denilerek "şayan-ı dikkat ve mütalaa" olduğu gerekçesiyle bu dilin incelikleri hakkında otuz sene önce "bir zâtın kaleminden" çıkmış olduğu belirtilen "Fârisî Lisânına Dâ'ir Malûmât"ll başlığı ile Farsçanın tarihi hakkında bilgi veren bir makale göze çarpmaktadır. Dergide edebiyatla ilgili nispeten uzun iki tefrika bulunmaktadır. Bunlardan "Sanat-1 Hatt” başlıklı birinci yazı üçüncü, dokuzuncu ve onuncu sayılarda tefrika edilmiştir. Yazının önemi ve anlamı hakkındaki girişin ardından sözü Arapçaya getirerek “Türkinin albafesi yoktur Arabiyi kullanır bu nedenle Arabça hakkında bilgi verelim" "12 şeklinde başlayan bu makalenin önemi, konuyla ilgili kaynakları arasında açıkça yazar ve eser adı zikredilerek İbn Haldun'un (1332-1406) Mukaddime'sini kaynak göstermesidir. Derginin ad değişikliği ile başlayan ikinci döneminin sorumlusu Mahmûd Celâl Bey tarafından kaleme alınan bu yazının ikinci bölümü, derginin onuncu sayısında sona ermektedir. Bu bölümün sonunda Iraklı meşhur kâtip Abdülhamid'in (öl. 750) vaktiyle kâtiplere vasiyet için yazdığı uzun bir mektubun tercümesi bulunmaktadır. "Mukaddime-i İbn Haldun'dan ayniyle nakl u tahrîr kılındı"13 denilerek bu bölümün de yine İbn Haldun'nun ünlü eserinden ${ }^{14}$ alındığı belirtilmektedir. Bu yazı dizisinin üçüncü bölümü, on birinci ve on ikinci sayılarda "Gülbün-i İnşâ" başlığıyla devam etmektedir. On birinci sayıdaki bölümün sonuna konan yazı sanatı örneklerinden biri "San'at-1 Hatta Dâ'ir İbn Bevvâb'ın Kasîdesi”'15 başlığını taşımaktadır ki bu kasîdenin de yine İbn Haldun Mukaddime'sinden alındığ ${ }^{16}$ açıkça ifade edilmektedir. Edebiyatla ilgili uzun yazıların ikincisi ise, mütercimi Maarif-i Umûmiye Mektûbî Odası halifelerinden Hasan Subhi olan ve onuncu ve on üçüncü sayılarda tefrika edilen "Tercüme-i Hikâye-i Zübâb” başlıklı yazıdır.

10 Mecmûa-i İbretnümâ sayı 16 (Muharrem 1283 / Mayıs-Haziran 1866): 31.

11 Mecmûa-i İbretnümâ sayı 10 (Receb 1282 / Kasım-Aralık 1865): 35-41.

12 Mecmûa-i İber-i İntibâh sayı 3 (Muharrem 1280/ Haziran-Temmuz 1863): 73.

13 Mecmûa-i İbretnümâ sayı 10 (Receb 1282 / Kasım-Aralık 1865): 8.

14 Söz konusu mektubun günümüz Türkçesine uygun çevirisi için bkz. İbn Haldun, Mukaddime, c.1, çev Süleyman Uludağ (İstanbul: Dergâh Yayınları, 2004), 497-500.

15 İbn Bevvâb (öl. 1022), Orta Çağ İslâm dünyasının en önde gelen hattatlarındandır.

16 Mecmûa-i İbretnümâ say1 11 (Şaban 1282 /Aralık-Ocak 1865-1866):18. İlgili kasidenin günümüz Türkçesine çevirisi için bkz. İbn Haldun, Mukaddime, c.2, 749-750. 


\section{Tarih Yazıları}

Tefrikaların önemli kısmını tarihle ilgili yazılar oluşturmaktadır. Bu alanla ilgili yazı dizilerinin edebiyata ilişkin olanlardan daha fazla ve daha uzun olduğu görülmektedir. Dergide, Naima (1655-1716), Sultan Osman saltanatı, Kıbrıs Adası'nın tarihi, Çin ve İran tarihi hakkında yazılar bulunduğu ve hepsinin yazarının da derginin ilk dönem sorumlusu görünen Ali Haydar olduğu dikkati çekmektedir. İlk dönemde tarihle ilgili en uzun yazı, "Urbân Tarihi” başlığıyla eski Arap kabilelerinin tarihinden söz eden makaledir. Derginin iki, dört, beş, altı ve yedinci sayılarında tefrika edilen söz konusu yazı "Esbak-ı Müdîr-i Telgrâf” Arif Bey tarafından kaleme alınmıştır. Sorumluluğun Mahmûd Celâl Bey’e geçtiği ikinci dönemde de dergide tarihle ilgili yazıların önemli yer tuttuğu ancak konuların Arap, Emevî, Abbâsî, Hulefâ, Yemen gibi alanlara sıkıştığı görülmektedir. Dokuzunca sayıda başlanıp on, on üç ve on dördüncü sayılarda sürdürülen "Câmi-i Emevî Âsârına Dâi'r" başlıklı yazının, şeyhülislâm olduğu söylenen İmâduddîn el-İmâdi el-Hanefî' nin ${ }^{17}$ bazı tarih kitaplarından derleyerek yazdığı, nadir bulunan bir risalesi olduğu ve bu nedenle tercüme edildiği belirtilmektedir. ${ }^{18}$ Mütercimi, Meclis-i Vâlâ Mazbata Odası mütercimlerinden Hakk1 Bey'dir. İkinci dönemde Mahmûd Celâl Bey ile birlikte derginin yazı yükünü çeken Hakk1 Bey'in diğer bir yazısı on birinci ve on dördüncü sayıda tefrika edilen "Ahbâr-1 Mülûk-1 Sâlife"dir. Yazarın başka bir yazısı da on beş ve on altıncı sayılardaki "Tercüme-i Hâl-i Hülefâ-i Âl-i Abbâs"dır. Çok uzak olduğu için fazla bilinmediği gerekçesiyle kaleme alınıp bölgenin Osmanlıya geçiş tarihi hakkında bilgi vermeyi amaçlayan ve on beş ve on altıncı sayılarda tefrika edilen "Malûmât-1 Hıtta-i Yemâniye" başlıklı yazı ise Mehmed Muîn Bey tarafından kaleme alınmıştır.

Son olarak, yine Mahmûd Celâl Bey tarafından kaleme alınan ve "Asâr-1 Bahriye" başlığını taşıyan denizcilik tarihiyle ilgili yazı da derginin tarih yazıları kategorisinde değerlendirilebilir. Denizlerin ve dolayısıyla denizciliğin öneminden, bizde dönemin padişahının her alanda olduğu gibi denizciliğe de önem verdiğinden söz eden uzun bir girişin ardından dergi, yazının niçin kaleme alındığını şöyle açıklamaktadır: "Cemiyet-i Kitâbet işbu mecmûa[da] ... tabaka-i Islâmiyânın kuvve-i bahriyesinin suver ve eşkâl-i atîka ve bazı fütûhât-ı mühimmesini ve Devlet-i Aliye-i Osmâniye'nin her asrda tahavvül ve tebeddül iden süfün-i harbiyesi ahvâlini temhîd ve tafsîle şurû ve mübâşeret eylemişdir". ${ }^{19}$ Ardından ilk gemiyi Tufandan önce Nuh peygamberin yaptığından bahisle, on iki ve on dördüncü sayılarda, İslam'dan önceki Arapların ve çağdaşları Avrupalıların denizcilikteki seviyeleri anlatılmakta, "bakiyesi sonra" denilmesine rağmen önceki birçok yazı gibi bu makalenin de bitirilemediği görülmektedir.

17 Şam müftüsü olup çeşitli medreselerin yanı sıra adı geçen camide de dersler veren Hanefî fıkıhcıdır (öl. 1758).

18 Mecmûa-i İbretnümâ sayı 9 (Cemaziyelâhir 1282 / Ekim-Kasım 1865): 15.

19 Mecmûa-i İbretnümâ sayı 12 (Ramazan 1282 / Ocak-Şubat 1866): 6. 


\section{Felsefe Yazıları}

Dergide nadir de olsa felsefeye dair yazılarla da karşılaşılmaktadır. Yukarıda edebiyat alanına dâhil ettiğimiz "nesâyih" türü yazılar felsefeyle özellikle de ahlak felsefesiyle ilişkilendirilebilir. Nitekim ilk sayıda Ali Haydar Bey tarafından kaleme alınan "Nesâyîh-i Hukemâ" başlıklı iki yazıda, "hekîm-i hikmetşinâs Bokrat Aforizmo nâm telîfleri mukaddimesinde ... beyân eylediği gibi ..." "hekîm-i muhakkik Bokrat'dan suâl olundukda ...", "hukemâ-i Yunaniyeden Antisten nâm hakîmin kavlince...", "hakîm-i hikmetşinâs Diyojen ..." gibi ifadelerle ${ }^{20}$ eski Yunan bilginlerinin söz ve eserlerine dayanan ahlaki ögütler verildiği görülmektedir. Burada anılanların eski Yunan bilginlerinden sırasıyla Yunan tıbbının sembolü Koslu hekim Hippokrates (M.Ö. 460-377) ve Aforizmalar adlı eseri² ${ }^{21}$, kinizmin kurucusu Antisthenes (M.Ö. 422-365) ve ünlü kinik filozof Sinoplu Diyojen (M.Ö. 411-324) olduğu bilinmektedir. $^{22}$

Yeri gelmişken, derginin ahlaki öğ̈̈tler verip özendirmeler yapılan kısmında, on sekizinci yüzyıldan beri Avrupa'nın ünlü bankerlerinden sayılan Rothschild ailesi hakkında anlatılan ilginç bir öyküye yer verildiği belirtilmelidir. "Fâ'ide-i sâhîha doğruluktadır" diye başlayan bu öyküye göre, baba Rothschild, Frankfurt'ta orta halli bir sarraf iken, Fransa-Almanya savaşı yüzünden ülkeden kaçmak zorunda kalan dukalardan birinin para ve değerli eşyalarını emanet almış ve bunları işleterek zengin olmuştur. Çok sonraları emaneti geri isteyen dukanın varisine de hem emanetleri teslim etmiş hem de yüzde altı faiz vermiştir. Öykü, "bu doğrusu sadakatin derece-i nihâyetidir" ifadesiyle sonuca bağlanmaktadır. ${ }^{23}$

Dergide açıkça felsefeyle ilgili denilebilecek tek yazı altıncı sayıdaki, "Mektûb-1 Sadâret Hülefâsından Âlı̂" imzasıyla kaleme alınan "Yunan Hükemâ-yı Kadîmesinin Tercüme-i

20 Mecmûa-i İber-i İntibâh sayı 1 (Receb 1279 / Aralık-Ocak 1862-1863): 3, 25, 12,13.

21 Ayşegül Demirhan, Klsa Tip Tarihi (Bursa: Bursa Üniversitesi Yayınevi, 1982), 36-38.

22 Cemil Sena, Filozoflar Ansiklopedisi I (İstanbul: Remzi Kitabevi, 1974), 65-68, 552-554.

23 Mecmûa-i İber-i Íntibâh sayı 1 (Receb 1279 / Aralık-Ocak 1862-1863): 6-7. Sezai Balcı ve Mustafa Balcıoğlu tarafından "Başbakanlık Osmanlı Arşiv Belgelerine dayanılarak" hazırlanan Rothschchildler ve Osmanlı Imparatorluğu (Ankara: Erguvani Yayınevi, 2017) adlı eserde Osmanlı Devleti ve Rothschildler arasında, İkinci Mahmud döneminde 1828-29'daki Osmanlı Rus savaşı sırasında Tuna ordusu için ancak yarı parası ödenerek buğday satın alınabilmesiyle başlayan ilişkilerin devletin yıkılışına kadar sürdüğü belirtilmektedir. Aile, 1834'de Yunanistan'ın, Osmanlıya ödeyeceği savaş tazminatına aracılık ederken, aynı yıl devletin açacağı elçilikleri finanse etmiş, 1853 'te Kırım Harbi öncesi on milyon kuruşluk silah alımı ve 1855 'te de savaş sırasında artan savaş masraflarının karşılanması için Mısır ve İzmir gümrük gelirleri karşılığında devlete önemli borçlar vermiştir. Savaş sonrasında ise, İngiltere ve Fransa'nın garantörlüğünde Osmanlıya beş milyon sterlin borç vermiştir. Diğer ikisi 1891 ve 1894 yıllarında olmak üzere, Osmanlı Devleti'nin 1854-1914 yılları arasında aldığı kırk bir dış borcun üçü Rothschild ailesinden sağlanmış olup bu borçlar ancak Cumhuriyet Dönemi’nde ödenebilmiştir. Bkz., Necati Çavdar "Rothschildler ve Osmanlı İmparatorluğu”, Sezai Balcı ve Mustafa Balcığlu'nun Rothschchildler ve Osmanlı Imparatorluğu adlı kitabının incelemesi, Gaziosmanpaşa Üniversitesi Sosyal Bilimler Araştırmaları Dergisi 12, 2 (2017): 267-271. Buna göre, kurucuları kâtip sınıfından devlet görevlisi olduğu görülen Mecmûa-i İber-i Intibâh'ın 1862'deki daha ilk sayısında ahlak abidesi olarak gösterdiği ve övdügü ailenin, o sıralar Osmanlı Devleti'nin en önde gelen dış borç kaynaklarından ve alacaklılarından olduğu, dolayısıyla bu övgünün hiç de nedensiz olmadığı anlaşılıyor. 
Hâlleri -Talis - mâbad" başlıklı makaledir. "Mâbad" ibaresi yazının önceki sayılarda başladığını gösteriyorsa da önceki sayılarda böyle bir makale yoktur. Söz konusu tefrikada Thales'in yanı sıra Yedi Bilgelerden "Beyâs" yani Bias hakkında da bilgi verilmektedir. ${ }^{24} \mathrm{Bu}$ yazı dizisinin tefrikasına derginin sonraki sayılarında da tesadüf edilmemektedir. ${ }^{25}$

\section{Haberler ve Eser Tanitımları}

Dergide bazıları tarihsel ve kültürel bakımdan önemli görülebilecek güncel haber yazıları da yer almıştır. Bunlardan "Hasene-i Câriye" başlıklı olanında, İzmit'e yakın İstanbul'a dört saatlik mesafede Kartal kasabasının su sıkıntısı haber yapılmakta, deniz kenarındaki bu kasabanın Yakacık gibi içilebilir su kaynağına bir saat mesafede olmasına karşın sağlıklı içme suyunun bulunmadığı, bu nedenle kasabada birçok hastalık ve zarar oluştuğu söylenmektedir. Habere göre, kimsenin el atmadığı bu mesele, bir saatlik mesafede bulunan Ballıdere'nin latif suyunun Kartal'a akıtılmasıyla çözülmüştür. Bu hayırlı işin masraflarını “esbâk Mısır vâlîsi büyük Mehmed Alî Paşa'nın kerîme-i muhteremeleri...Zeyneb Hânım Efendi Hazretleri" üstlenmiştir. Cemiyet-i Kitâbet bu yardımdan ötürü Zeynep Hanım'a teşekkürlerini bildirmektedir. ${ }^{26}$

Sekizinci sayıdaki bir haber, kültür ve eğitim tarihimiz açıdan önemlidir. "Tasvîr 'i Efkâr 'in neşr eylediği bir benddir" başlıklı bu haber Dârüşşafaka ve kurucusu olan topluluk ile ilgilidir. Habere göre, "Asnâfdan istiyanlara umûr-ı itikâdiye ve hisâbiye talim itmek ve mehmâ emken Türkçe okudub yazdırmak üzere bazı zevât Cemiyet-i Tedrisiye-i İslâmiye nâmıyla bir heyet teşkîl... ve çarşu civarında bir mekteb dahî istemiş olduklarından" Bâbıalî’ye yaptıkları başvuru sonucu gereken izin alınmıştır. Haberde, topluluğun biri idarî diğeri eğitim işleriyle ilgilenen iki üye grubu bulunduğu ve istedikleri okul tamir gerektirdiğinden durumun Bâbıalî tarafından Evkâf'a havale edildiği bildirildikten sonra burada okutulacak dersler hakkında da bilgi verilmektedir. Buna göre, öğrencilere sabahları bir veya iki saat elifba, kelâm-1 kadîm,

24 Mecmûa-i İber-i İntibâh say1 6 (Ramazan 1280 / Şubat-Mart 1864): 165-169.

25 Elimizdeki sayının sayfalarının eksik olmasından ötürü derginin yedinci sayısını bu ifadeden hariç tutuyoruz.

26 Mecmûa-i İber-i Íntibâh sayı 3 (Muharrem 1280 / Haziran-Temmuz 1863): 91-93. Zeynep Hanım, babası Misır Valisi Kavalalı Mehmed Ali Paşa tarafından, Mısır'a gelip yaptığı hizmetlerle gözüne giren Yusuf Kamil Bey ile evlendirilmişti. Kavalalı'nın ölümünün (1849) ardından evliliğe son vermek isteyen Mısır sarayının baskısından Osmanlı sarayınca kurtarılıp İstanbul'a getirildikten sonra Osmanlı Devleti’nde sadrazamlığa (1863) kadar yükselecek Yusuf Kamil Paşa (1808-1876) ile eşi Zeynep Kamil Hanım, ülke tarihinde yardımseverlikleriyle de iz bırakmışlardır. Bunlar arasında Üsküdar'da yaptırdıkları (1882) yüz yataklı kadın hastanesi günümüzde Zeynep-Kamil Kadın ve Çocuk Hastalıkları Hastanesi adıyla hâlâ hizmet vermeye devam etmektedir. Bkz. Feza Günergun, Şeref Etker ve Abdullah Köşe, "Zeynep-Kamil Hastanesi'nin Kuruluşu ve Vakfiyesi," Osmanlı Bilimi Araştırmaları 5, 2 (2004): 1-37. Arapça, Farsça ve Fransızca bilen Yusuf Kamil Paşa, 1862'de Fenelon'dan (1651-1715) yaptığı ve 1863,1870, 1877, 1881'de tekrar tekrar basılan Tercüme-i Telamak adlı çevirisi nedeniyle kültür tarihimiz bakımından da önemlidir. Bkz. Süleyman Beyoğlu, "Yusuf Kamil Paşa," TDV Íslâm Ansiklopedisi, c.24 (Ankara: Türkiye Diyanet Vakfi, 2001), 283-284. Nitekim, Mecmûa-i İber-i Intibâh'ın yine üçüncü sayısının başlarındaki "Teşekkürnâme” başlıklı yazıda “Tercüme-i Telemak'ın hikemî ahkâmıyla âmil bir vezir-i kâmil" olduğu söylenen Yusuf Kamil Paşa'ya derginin yayınlanmasına yönelik teşvikleri için teşekkür edilerek “İber-i İntibâh'ın her nüshasının bir eser-i cedid olacağg”" sözü verilmektedir. 
ilm-i hâl, Türkçe kitâbet, hisâb, hendese, coğrafya mukaddemâtı ve tarih okutulacaktır. Tahsil malzemeleri topluluk tarafından karşılanacağı gibi başarılı öğrencilere teşvik ödülleri verilecektir. Bu nedenle her isteyenin başvurması uygun görülmüştür. Haberde, kurucuların devlet görevlileri olduğu ve boş zamanlarının bir kısmını bu işe harcayacakları bilgisinin ardından bu hayırlı işin hüsn-i kabûl gördüğü ifade edilmektedir. ${ }^{27}$

Dergide, yeri geldikçe, dönemin çeşitli bilginlerinin telif veya tercümeleri de okuyuculara duyurulmaktadır. Bunların birinde, Kilîs bilginlerinden Hocazâde demekle meşhûr olan Abdullah Efendi'nin' “âdâb-l mîr Bâbıâlî̀ye gönderildiği bildirilerek Cemiyet-i Kitâbet'in bu tür "teceddüden te'lîf olunan" faydalı yayınları duyurmayı ve yazarlarına teşekkür etmeyi önde gelen vazifelerinden saydığı ifade edilmektedir. ${ }^{29}$ Bir başka sayıda üç yeni eserin yazıldığından söz edilmektedir. Bunlardan birincisi devlet büyüklerinden olduğu belirtilen Fâzıl Paşa'nın ${ }^{30}$ Mevlânâ Celâleddin-i Rûmî'ye nisbet edilen Hakâyık-ı Ezkâr-ı Mevlâna üzerine yazdı̆̆ı açıklama [Şerh-i Hakâyık-ı Ezkâr-ı Mevlâna], ikincisi Bursa Mekteb-i İdâdiye-i Şâhane'si Fârisî hocası Mustafa Bey’in Şeyh Şehâbeddîn Sühreverdî’nin Cevâbnâme tercümesidir. Dergi, söz konusu paşanın, masrafları kendisine ait olmak üzere basımına izin verilen eserinin, sülûk edeceklerin Mevlevîliğin âdâb ve erkânını ayrıca Mevlevî ahlâk (nesâyih) ve hikmeti öğrenmeleri bakımından önemli olduğunu belirterek her iki eserden dolayı Cemiyet-i Kitâbet'in duyduğu hoşnutluğu dile getirmektedir. Duyurusu yapılan üçüncü eser ise, derginin yazarlarından olan Maârif-i Umûmiye Mektûbî Odası hulefâsından Hasan Subhî Efendi'nin ${ }^{31}$ Farsça gramer kitabı olduğu söylenen Gencine-i Hüner' idir. ${ }^{32}$ Derginin, bu yayın dolayısıyla, peygamberlerin bazı beliğ sözlerinde Farsça kelimeler bulunması ve ayrıca Arapça gibi Farsçanın da hem cennet ehlinin dili hem de göğün dördüncü katındaki büyük meleklerin dili olduğuna ilişkin rivayetlerden hareketle Farsça hakkında bir yazıya yer vermesi dikkat çekmektedir.

Bir başka duyuruda, 'eski Magribli bilginlerdendir' denilen Kâdı Adûduddîn'in Arapça Tehzîbu'l- Ahlâk-ı Insâniye'sinin adı belirtilmeyen Tire müftüsü tarafinda Türkçeye tercüme

27 Mecmûa-i İber-i Íntibâh sayı 8 (Muharrem 1281 / Haziran-Temmuz 1864). Elimizdeki nüshada sekizinci sayının sayfa numaraları tahrip edilmiş olduğundan ilgili sayfa numaralarını belirleyemiyoruz.

28 Hocazade Abdullah Enverî (1835-1887).

29 Mecmûa-i İbretnümâ sayı 9 (Cemaziyelâhir 1282 / Ekim-Kasım 1865): 23-24.

30 Edirne müderrisliği, Bosna kaymakamlı̆̆ı, Belgrad mollalığı, Bosna vergi tahsildarlı̆̆ı gibi çeşitli görevlerin ardında mirliva rütbesi alıp 1845 'te Galata Mevlevihanesi şeyhine intisap eden Mehmed Fazıl Paşa (17951882) on dokuzuncu yüzyıl divan şairlerindendir. Bkz, Mehmet Arslan, "Fâzıl Bey," Türk Edebiyatı İsimler Sözlüğ̈̈ (TEISS), erişim tarihi: 18.08.2021, http://teis.yesevi.edu.tr/madde-detay/fazil-pasa.

31 İstanbullu olduğu sanılan Hasan Subhi Efendi, söz konusu kalemden sonra görevli olarak Haleb’e gönderilmiş, orada otuz yaşını dolduramadan ölmüştür. Otuz beş sayfalık anılan Farsça risalesinden başka, Mecmua-i İbretnüma' da yayınlanan Tercüme-i Hikâye-i Zübâb adlı Fransızca'dan yapıldığı sanılan çeviri de Hasan Subhi imzalıdır. Bkz, Mehmet Arslan, "Subhi, Hasan Subhi," Türk Edebiyatı İsimler Sözlüğü (TEİS), erişim tarihi: 18.08.2021, http://teis.yesevi.edu.tr/madde-detay/subhi-hasan-subhi.

32 Mecmûa-i İbretnümâ sayı 10 (Receb 1282 / Kasım-Aralık 1865): 33-34. 
edilip basımı için gerekli izinlerin alındığından söz edilmektedir. Bu haberin altında imzası olan dergi yazarı Hakkı Bey, söz konusu eseri bildiğini ve eserin her biri pek çok fayda içeren dört makaleden oluştuğunu ifade ederek, mütercime, emekleri için topluluğun teşekkürlerini sunmaktadir. ${ }^{33}$

Dergide, sadece klasik kültür eserlerimizden bahsedilmediği görülmektedir. On üçüncü sayıda, Mekteb-i Tıbbiye-i Şâhâne Nâzırı Salih Efendi'nin daha önce Dârülfünûn'da halka "Târîh-i Tâbîî" dersleri verdiği, ancak bu dersin sonraki bilginlerin araştırmalarını içeren Türkçe bir kitabı bulunmadığını belirten bir haber şöyle devam etmektedir: Bavyeralı Doktor Arnes adlı bir muallimin, Fransızcaya da çevrilmiş olan hayvan, bitki ve madenler hakkında muhtasar bir risalesi vardır. Salih Efendi bu eseri, girişini padişaha övgülerle süsleyerek Türkçeye çevirmiştir. Tercüme, Matbaa-i Âmire'de basılıp rüşdiyelere dağıtıldığı gibi satışa da çıkarılmıştır. Yazıda tercümenin baskı özellikleri hakkında da bilgi verilmektedir. Buna göre tercüme, seksen dokuz sayfadır. Yirmi beş levha ve iki yüz doksan hayvan ve bitki şekli içermektedir. Eserde hayvan ve bitkilerin tür ve cins isimleri (furûk $k^{34}$ ve sunûf) resimlerin altına Türkçe ve Fransızca olarak yazılmıştır. ${ }^{35}$

Bu haberin devamında "Mecmûa-i İbretnümâ İstitrâd" başlığıyla yapılan açıklama bize Cemiyet-i Kitâbet'in ve dergisinin zihniyetini anlamak bakımından önemli ipuçları verebilecek özelliktedir. Burada, eski İslâm bilginlerinin (mütekaddimîn) hayvan ve bitkiler hakkında pek çok önemli eserler yazdıkları, İslâm ülkelerinin kütüphanelerinin bunlarla dolu olduğu, ancak çoğunun, belki de tamamının, "azbu'l-beyân Arabî” yazıldığı ve bunların Türkçeye tercüme edilmişlerinin çok nâdir olduğundan hareketle şöyle söylenmektedir. Özellikle "tabaka-i İslâmiyenin karnı-ı evvelinde" yazılmış bu tür eserlerin, şimdiki asrın anlayışına (istidâd) uygun olarak tercümeye girilmemiş olması bunlardaki hikmetler, cevherler ve bilgilere ulaşılmasına engel olmuştur. Dergi bu nedenle, Orta Çağ Müslüman bilginlerinden Sirâcuddîn Ebî Hafs Omer b. el-Verdî’nin (öl. 1457?) Cerîdetü'l-Acâyib ve Ferîdetü'l-Garâyib adlı eserinden zooloji, botanik, meyvelerin dikimi ve özellikleri hakkında faydalı bilgiler içeren bir faslın tercüme edilip daha sonra yayımlanacağını bildirmektedir. Öte yandan Arendts'in kitabının sonraki bilginlere (müteahhirîn) göre olduğu ve tercümesinin

33 Mecmûa-i İbretnümâ sayı 11 (Şaban 1282 / Aralık-Ocak 1865-1866): 28-29.

34 Metinde bitki takımı (ordre) için kullanılan firka teriminin çoğulu olan firâk terimi yerine hatalı olarak ferîk kelimesinin çoğulu furûk yazılmıştır. Fıkra terimi için bkz. Bkz. Asuman Baytop, "Hekimbaşı Salih Efendi'nin (1816-1895) Kullandığı Botanik Terimler,” A. Baytop, Türkiye'de Botanik Tarihi Araştırmaları (Ankara: TÜBİTAK, 2004), 235- 261 içinde 245.

35 Mecmûa-i İbretnümâ sayı 13 (Şevvâl 1282 / Şubat-Mart 1866): 2-3. Buradaki "Bavyeralı doktor Arnes," 1869'da Münih'teki Coğrafya Cemiyeti'nin kurucularından olup başkanlığını da yapan Carl Arendts'tir (18151881). Salih Efendi İlm-i Hayvânât ve Nebâtât adlı tercümesini, bu bilginin Almanca kaleme aldığ Arendts Naturhistorischer Schulatlas adlı eserinin, Dr. Royer tarafından 1859'da gerçekleştirilen Fransızca çevrisinden yapmıştır. Salih Efendi'nin tercümesi, söz konusu derginin de vurguladığg üzere, Türkiye'de botanik eğitiminde kullanılmış aynı zamanda resimli olan ilk Türkçe eserdir. Bkz, Feza Günergun ve Asuman Baytop, "Hekimbaş1 Salih Efendi (1816-1895) ve Botanikle İlgili Yayınları,” Osmanlı Bilimi Araştırmaları 2 (1998): 295-301. 
çocuklarımıza çok yararlı olacağını belirten Cemiyet-i Kitâbet, hem ilimler ve fenlerin gelişmesi için gerekli izinlerinden ötürü padişaha, hem de mütercime teşekkür etmektedir. ${ }^{36}$

Beşinci sayıdaki "Coğrafya Lügati” başlıklı ve "Ali Haydar” imzalı yazı, aslında bir kitap haberidir. Dergi ülkede coğrafyayla ilgili pek çok eser (risâle) bulunmasına karşın yabancı dilden tercüme edilmiş bir coğrafya lügati bulunmadığı ve böyle bir lügatin çevirisinin ilk kez Mustafa Nâ'ilî Paşazâde Sâlih Paşa tarafından birkaç ay içinde tamamlanıp sadrazam Fuad Paşa’ya (Keçecizâde, 1815-1869) ithafen yayınlanacağı müjdesini vermektedir. Haber verilirken Osmanlı kültüründe Avrupalılaşma ya da modernleşme sancılarının başladığına veya yaygınlaştığına işaret eden ifadelerle karşılaşılmaktadır. Şöyle ki ülkede Avrupa'nın bize gerekli olan "maârif ve sanâyi”ni yaymak Avrupa'ya gidip gelen veya yabancı dilleri ülkemizde öğrenmiş olanların zorunlu görevidir. Ancak bu seçkin zümre Avrupâî yeni yöntemler (adât-ı tâzege-i ecnebiye) adıyla medeniyeti tahkîr edecek bir takım usuller getirmeye çalışmamalıdır. Bunlar zaten halk nazarında kabul görmeyecektir. ${ }^{37}$

Dergideki haberlerden biri de Mir'at adlı maârif ve sanayiye dair yeni bir resimli derginin yayım hayatına başladığını ve yayımcısının, bu güzel hizmetinden ötürü tebrik edilen Mezâhib Odası hülefâsı ser-âmedânından Refîk Bey olduğunu bildirmektedir. ${ }^{38}$

\section{Cemiyet-i Kitâbet ve Cemiyet-i İlmiye-i Osmaniye Arasındaki Polemikler $^{39}$}

Mecmûa-i İber-i Intibâh'ın üçüncü sayısının "târîh-i hudûsı bir seneyi mütecâviz olan Mecmua-i Fünûn'un sekizinci nüshasında risâlemiz hakkında yazılan makâlât ile ecvibemizdir" ifadesiyle başladığı görülmektedir. Gerçekten Cemiyet-i İlmiye-i Osmaniye'nin yayını olan Mecmua-i Fünûn'un yöneticisi ünlü Münif Efendi [sonradan paşa] (1830-1910) dergisinde "Hüdûs-i Mecmûa-i İber-i İntibâh" başlıklı bir yazıda hem derginin çıkışını haber vermiş hem de dergiye bazı eleştirilerde bulunmuştur. Münif Paşa yazısında, “yeni bir fünûn gazetesi” olarak vasfettiği Mecmûa-i İber-i Intibâh'ın ilk sayısındaki tüm yazıların daha önce Tercümân-ı Ahvâl' de görüldüğünden içinde yeni bir şey bulunmadığını, sayfa sayılarının kendi dergilerinin yarısı kadar olduğunu ve iki ayda bir çıkacağı için şimdilik "erbâb-l fünûnun" dikkatini çekemeyeceğini ileri sürmüştür. Ancak ona göre henüz bir "tohm-ı sagîr" (küçük tohum) olan derginin, gayretlerle büyüyüp faydalı olabileceği ümid edilebilir. Bu tür yayınların az veya çok bir etkisi mutlaka olacağından ve derginin, asıl kendi

36 Mecmûa-i İbretnümâ sayı 13 (Şevvâl 1282 / Şubat-Mart 1866): 4-5.

37 Mecmûa-i İber-i İntibâh sayı 5 (Şaban 1280 / Ocak-Şubat 1864): 153-155.

38 Mecmûa-i İber-i İntibâh sayı 2 (Şevvâl 1279 / Mart-Nisan 1863): 55.

39 Bu polemiğin Ulusoy Nalcığlu'nun da dikkatini çektiği ve daha önce makalesinde ayrıntılı olarak incelemiş olduğu görülüyor. Söz konusu makaleden, benzer bir polemiğin bu kez Mecmua-i Fünûn ile yine o dönem yayımına başlayıp üç sayı sonra kapanan Mirat dergisi arasında da yaşandığını öğreniyoruz. Bkz. Belkıs Nalcığlu Ulusoy, “Türkçe Dergiciliğinin Sancılı Başlangıcı,” Dergicilik Üzerine, editör Aslı Yapar Gönenç (İstanbul: Koyu Kitap, 2013) içinde, 7-39. 
topluluklarının maksadı olan bilgiyi yayma işinde bir yardımı dokunacağından yaptıkları iş memnuniyet sebebidir ve teşekküre şayandır. Öte yandan Münif Paşa, bu tür dergi çıkarma heveslilerinin şevk ve gayretini yok edebilecek tavır ve sözlerden kaçınmak gerektiğini belirtmekle birlikte, sözü geçen cemiyet ve derginin adı hakkındaki görüşlerini açıklamaktan da geri kalamayacağını ifade ederek bu konuda aşağıdaki eleştirilerde bulunur.

Öncelikle Cemiyet-i Kitâbet'in kuruluş şekli, tüzüğü, üyeleri, amacı ve toplantı yeri duyurulmadığından bilinmesi gereken amaçları "gizli" kalmıştır. Yazdıklarına bakılırsa, amaçlarının halka "inşâ ve kitâbet” yöntemini öğretmek olduğu anlaşılmaktadır. Fakat adları bu amaca uygun değildir. "Kitâbet” kelimesi, Fransızca littéraire sözcügüunün tercümesi ise bu durumda kendilerine "Cemiyet-i Edebiye" denilmek daha uygun olurdu. Dahas gazetenin adındaki "İber-i Intibâh" tamlaması eğer sıfat tamlaması (vasf terkîbi) ise, Farsça kurala uymamaktadır. Bu nedenle arada bir "vâv-l âtıfe" [yani dergi adı Mecmâ-i İber u Intibâh şeklinde] olmalıdır. Ancak adı "Kitâbet" olan bir topluluğun böyle bir hatâ yapması mümkün görülmediğinden bu "vav"ın unutulması dalgınlıkla yapılmış bir hatâ (sehven zühûl) olmalıdır. Münif Paşa, bu görüşleri sadece görünüşü düzeltmek (def-i eşkâl) amacıyla yazdığını ve Cemiyet-i Kitâbet'in kendisini affetmesini söyleyip bundan böyle ortak amaçlarının gerçekleşmesi için yardımlaşma temennisinde bulunarak eleştirilerini bitirmiştir. ${ }^{40}$

Mecmûa-i İber-i Intibâh, Münif Paşa'nın bu eleştirilerini paragraf paragraf nakledip her paragrafın ardından eleştirileri cevaplandırmıştır. Buna göre Tercümân-ı Ahvâl'deki bazı yazıların dergiye alındığı doğrudur ancak bu durum daha birinci sayıdaki mukaddimede açıklanmıştır. Öte yandan Мecmua-i Fünûn'da da tekrar edilen maddeler vardır. Derginin ilk sayısında sayfa toplamının Mecmua-i Fünûn'unkine oranla az olduğu doğrudur. Fakat üçüncü nüshada bu sayı ona yaklaşmıştır. Ayrıca zamanla artacaktır. Öte yandan Mecmua-i Fünûn gibi yardım merhamet dilenerek (bi’l-istitâf) önemli destekler sağlanıp parasız toplantı yeri ve müşteri bulunsaydı Mecmûa-i İber de iki ayda bir değil ayda iki kez çıkarılabilirdi.

Cemiyet-i Kitâbet'in derginin ismine yönelik eleştirilere verdiği cevapların daha sert olduğu ve sonunda sadece Münif Paşa'yı değil Cemiyet-i İlmiye-i Osmaniye’yi de cahillikle suçlamaya vardığı görülüyor. Buna göre "İber-i Intibâh" deyimi bir isim tamlamasıdır (terkîb-i izâfî) ve bir şüphe veya hatâ içermemektedir. Dergi adı, ya uyananlar için (ehl-i intibâh) ya da uyanma (intibâh) için "İber Mecmûası" şeklinde iki türlü anlaşılabilir. "İber" kelimesi geçiş yeri (mahall-i iber) demek olduğundan uyanma geçidi (intibâhın memerri) ya da uyanışa götüren (intibâha delâlet) anlamları da doğru olur.

Sıfat tamlaması (vasf terkîbi) konusuna gelince, “İber-i İntibâh" deyiminin sıfat tamlaması olduğu fakat Farsça kurala göre yanlış kullanıldı̆̆ı araya "vav" harfinin konması gerektiği, iddiaları doğru değildir. Muciz-i beyân vb. gibi ifadelerde görüldüğü gibi iki Arapça kelime

40 Mecmua-i Fünûn say1 8 (Şabân 1279 / Ocak-Şubat 1863): 353-355. 
arasında da sıfat tamlaması olabilir. Zaten dergi adında araya "vav" harfi konulmaması, bunların niteleyen-nitelenen (sıfat-mevsûf) yani sıfat tamlaması olmadığını açıkça göstermek içindir. Böylece isim tamlaması olduğu açı olan bir ifadenin sıfat tamlaması olarak tartışılması abesle iştigaldir. Eğer arada bir "vav" olsaydı asıl bu "vav" harfi "sehven zühûl" olurdu. Cemiyet-i Kitâbet, kendilerine yönelik eleştirileri, Cemiyet-i İlmiye-i Osmaniye gibi büyük bir unvanı bulunan bir heyetin doğru bir ifade üzerinde bu tür bir dizi hata ile gaflette olmasının esef verici olduğunu ancak yine de aflarını rica ettiklerini ifade ederek bitirir. ${ }^{41}$

Polemiğin sonraki sayılarda da sürdüğü görülmektedir. Mecmua-i Fünûn'un dokuzuncu sayısında, Mecmûa-i İber-i Intibâh'ın ardından bu kez Mir'at adında bir "fünûn gazetesi" daha çıktığı duyurulup "intişâr-ı maârif” adına duyulan memnuniyet bildirilmektedir. Ardından iğneleyici biçimde çoktan beri böyle bir ihtiyaç olmasına rağmen kimsenin bu işe girişemediği ancak kendi dergileri çıkar çıkmaz birdenbire bu alanla ilgili iki gazete çıkmasının dikkat çekici olduğu vurgulanmaktadır. ${ }^{42}$

Mecmûa-i İber-i Intibâh'ın üçüncü sayısındaki cevabına asıl karş1lık Mecmua-i Fünûn'un on üçüncü sayısında “Mecmûa-i İber-i Intibâh'a Cevâb” başlıklı yazıyla verilmektedir. Cemiyet-i İlmiye-i Osmaniye imzalı bu yazı, topluluğun adı geçen derginin beş altı ay gecikmiş cevabını şaşkınlıkla ( $m a^{\prime}$-i istigrâb) karşılamaktadır. Ayrıca cevap edebî konuşmalara uygun olmadığı gibi edebî tartışmalar ile kişisel garezleri birbirinden ayıramamaktadır. Yeni çıkan bir derginin öncelikle içeriği, çıkış süresi ve yayınları sorgulanır. Mecmûa-i İber-i İntibâh'ın, Tercümân-ı Ahvâl'deki yazıları tekrar ettiğini, iki ayda bir kere neşr olunduğunu söylemek durum tespitidir. Bunu bir saldırı (tarîz) gibi görüp hemen cevaba kalkışmak üzüntü vericidir. Yine Mecmûa-i İber-i Intibâh, ismine yönelik şüpheleri gidermek için Cevâ 'ib gibi [Arapça gazeteler]den değil Veysî ve Nergisî gibi Türkçe münşeatlardan delil getirilmeliydi. Okullarda okutulması amaçlanan bir derginin olabildiğince kolay ve sade bir dille yazılması gerekirken en başta ismi şüpheli ve karmaşık olmamalıydı. Cemiyet-i Kitâbet'in aslında uyarılar sonucu bu durumu fark etmiş olmasına rağmen sonradan sebep uydurma (talîl bade'l-vukî) yoluna girerek birtakım kanıtlarla aleni hatâsında ısrar etmesi üzüntü vericidir. Мecmua-i Fünûn'un Saltanat-1 Seniye tarafindan desteklenmesine gelince bu gıpta edici durum, dergi daha çıkmadan değil dört beş sayısı çıktıktan sonra gerçekleşmiştir. Öte yandan Mecmûa-i İber-i Intibâh iki ayda bir çıkacağını söylemesine karşın ilk üç sayısına bakılınca gerçekte üç ayda bir çıkarılmaktadır. İleri sürüldüğü gibi Мecmua-i Fünûn'da tekrar edilen konular yoktur. Bununla "Telemak Tercümesi" kastediliyorsa yeni çıkan bir eseri tanıtmak, vakti olmadığı için okuyamayacaklara özetlemek, bir bilim dergisinin görevleri arasındadır. Bu bakımdan Cemiyet-i Kitâbet en önce gelen görevlerinden bî-haberdir. Mecmua-i Fünûn' daki bir yazının başlığı olan "Alâim-i Semâviye” ibaresi açıkça sıfat tamlamasıyken, isim tamlaması olduğunu

41 Mecmûa-i İber-i İntibâh sayı 3 (Muharrem 1280 / Haziran-Temmuz 1863): 64-70.

42 Mecmûa-i Fünûn say1 9 (Ramazan 1279 / Şubat-Mart 1863): 399. 
iddia etmek ve bunu kendi durumlarıyla kıyaslamak Cemiyet-i Kitâbet'in tuhaflığıdır. Mecmûa-i İber-i İntibâh, Mecmua-i Fünûn'un hatasını bulmak için düzgün bir ibare olduğu halde "sehven zühûl" tabirini öne çıkarmağa çalışarak en halisane yardımlaşma temennilerini fena bir şey zannetmiştir. ${ }^{43}$

Cemiyet-i Kitâbet'in bu eleştirilere yanıtının öncekinden daha sert olduğu görülmektedir. Buna göre Mecmûa-i İber-i Intibâh dergisinin adındaki tamlamada kusur yoktur. Önceki cevaba şaşıran Cemiyet-i İlmiye-i Osmaniye, şaşkınlığını “ $m a$ 'a'l-istigrâb” deyimindeki “harf-i tarifi” unutarak göstermiştir. Ellinci sayıda değil de üçüncü sayıda verilen bir cevaba gecikmiş denemez. Eğer bir gecikme varsa bu sırf insaniyet gereğidir. Cemiyet-i İlmiye-i Osmaniye, Kuran ayetleri ve el-Cevâ'ib'den deliller içeren ikna edici açıklamaları dikkate almayıp sözü değiştirmek yerine ya sıfat tamlaması konusundaki hatasını kabul etmeli ya da bu konudaki görüşlerini açıklamalıdırlar. Sıfat tamlamalarında, tamlama lâmı (lâmu'lizâfe) kullanmak "tayîn ve tedvîn olunmamış olan Türkî kavâidinde...câ'iz değildir". Bunun örnekleri hem Mecmua-i Fünûn'un tefrikalarında hem de delil istenen Veysî ve Nergisî münşeatlarında hatta asrımızda Türkçeye giren "hülâsa-i politika" gibi deyimlerde görülmektedir. Cemiyet-i İlmiye-i Osmaniye, rüşdiye çocuklarının bile bildiği bir konuyu karıştırıp isim tamlamasını sıfat tamlaması zannetmektedir. “İber-i İntibâh” Türkçe'de en çok kullanılan kelimelerdendir. Cemiyet-i Kitâbet, bu gibi itirazlarla doğru bir ibareyi halka yanlış göstermeyecektir. "Müsaadât-l Celîle"nin nedeni Mecmua-i Fünûn'un değerinden değil "neşr-i maârife" gösterilen özendendir. Мecmua-i Fünûn'da bulunduğunu söylenen tekrarlar "Tercüme-i Telemak" tefrikası için değildir. Diğer bir tefrikanın adı olan "Alâim-i Semaviye"de ileri sürülenin aksine, "sema" ismine yapılmış bir tamlamadır: Burada isimle müsemmâ uygunluğu olmayıp, tamlamanın doğru yazılışı “Alâim-i sema" şeklinde olmalıdır. "Alâim-i Semaviye" tamlamasında yanlışlık yapıldığını (sehven zühul) kabul etmek yerine doğruluğunda 1srar etmekle asıl Mecmua-i Fünûn, yaptığı yanlışa bahane (talîl bade'l-vukû) bulma yoluna sapmaktadır. Местиа-i Fünûn'un söylediği şeylerin tümü anlamsızdır; açıkça hiç anlamı olmayan bir deyimin kurala uygunluğunu kabul etmekte ve bunun eski ünlü bilginlerin eserlerinde sıkça görülen bir deyimden daha fasih (açık ve doğru) olduğunu iddia etmektedir. ${ }^{44}$ Bilindiği üzere bu tartışmalara rağmen, dokuzuncu sayıda, dergi başlığında bulunan ve çok sağlam olduğunda ssrar edilen "İber-i İntibâh" tamlaması "İbretnümâ" olarak değiştirilecektir.

\section{Popüler Bilim Yazıları}

Dergide bazı önemli bilimsel makaleler yer almakla birlikte, başlığı bakımından bu izlenimi uyandıran bazı yazıların bilimsellikle hiç ilgisi olmadığı da görülmektedir. Sözgelimi, başlığından bilimin yararlarının anlatıldığı sanılan ikinci sayıdaki "Lütf̂”" imzalı "Fevâid-i

43 Mecmua-i Fünûn say1 13 (Muharrem 1280 / Haziran-Temmuz 1863): 30-35.

44 Mecmûa-i İber-i İntibâh sayı 4 (Rebiülâhir 1280 / Eylül-Ekim 1863): 135-142. 
Fünûn" başlıklı yazı incelendiğinde, insanın dünyadaki mutluğu için düşünce yüklü anlamlı sözler konuşması ve dünya ve ahretteki mutluluğu için de dindar olması gerektiği şeklinde, başlığıyla ilgisiz görüşler dile getirildiği anlaşılmaktadır. ${ }^{45}$

Buna karşılık daha çok haberler kategorisine girebilecek "Ahvâl-i Dâhiliye-i Memâlik-i Mahrûsa/Osmâniye” başlıklı yazının önemli sayılabilecek bilimsel bir içeriğinin olduğu dikkati çekmektedir. Ünlü edebiyatçı, şair ve tiyatro yazarı Abdülhak Hâmid Tarhan'ın (1852-1937) ağabeyi kaymakam Abdülhalik en-Nasûhî Bey (1836-1912) tarafindan kaleme alınan, bol bilimsel dipnotlar (hâşiye) içeren bu yazının, "Mukaddime" başlıklı bölümünde, yeryüzünden, yeryüzünün kara ve su olarak görünümünden, bunların birbirine olan oranından, karalardan (rub-ı meskûn) ve karaların yeryüzünü çeşitli denizlere/okyanuslara ayırdığından söz edilmektedir. Bu bölümün dipnotlarında yerin küreselliği, yerin merkeze doğru gittikçe artan 1sıs1, merkez 1sısının büyüklüğü, yer kabuğu, yerkabuğunun yerin büyüklüğüne oranı, yerin ekseni ve gece ile gündüzü doğuran eksen hareketi açıklanmaktadır. Ardından, Dünya'nın iki kutbundan, kutupların basıklığından, metre olarak ekvator çapından, eksen ve çevre uzunluklarından, Güneş'in 365 gün 5 saat 48 dakika 51 saniye 6 salise sürdüğü belirtilen yıllık hareketinden, mevsimlerin oluşumundan ve nihayet yüksek dağların yerin küreselliğini bozamayacağından söz edilmektedir. ${ }^{46}$ Sonraki tefrikada kıtalar, Felemenk-i Cedîd veya Yeni Hollanda denilen Avustralya ile birlikte beş kıta, kuzey ve güney yarımküre, kıtaların bu yarımkürelere göre durumu, aralarındaki dağlar, boğazlar, denizler vs.ye göre kıtaların coğrafî̀ sınırları ve yeri inceleyen bilimlerin önde gelenlerinden biri olan coğrafya hakkında bilgi verilmektedir. Bu bölümün dipnotlarında kıta adlarının nasıl ortaya çıktığı, okyanuslara göre kıtaların durumları ve Yunanca "vasfu'l-Arz" anlamına geldiği söylenen coğrafya bilimi hakkında açıklama yapılmaktadır. ${ }^{47}$

"Mukaddime"nin devamı olup makalenin dergide yayınlanan son bölümünü oluşturan üçüncü tefrikadan coğrafya ve jeoloji bilimleri, bunların kıyaslanması, kıtaların doğal sınırları ve enlem-boylam hakkında açıklamaların yanı sıra yazının amacı öğrenilmektedir. Buna göre, yazar çok önemli gördüğü ve dipnotların birinde “ilmu ahvâli'l-memleket” olarak tanımladığı istatistik bilimine dayanarak elinden geldiği kadarıyla içinde övünç duyarak yaşadığı Osmanlı Devletindeki ülkeleri istatistiksel özellikleriyle tanıtıp anlatacaktır. Bölümün dipnotlarında coğrafya bilimi, matematiksel (hendesî), siyasî, beşerî ve tarihî şeklindeki bölümleri, istatistik bilimi, tanımı, dalları ve konularından söz edilmektedir. $\mathrm{Bu}$ sırada, yazıyı bilim tarihimiz açısından önemli kılan görüş ve bilgilerle karşılaşılmaktadır. Şöyle ki, bilindiği üzere Osmanlıda Türkçe basılan ilk jeoloji kitabı Rusçuklu es-Seyd Mehmed Ali Fethi'nin (1804/5-1857), Al-Aqwâl al-Murdiya fì 'ilm Bunyat al-Kura adlı

45 Mecmûa-i İber-i İntibâh sayı 2 (Şevvâl 1279 / Mart-Nisan 1863): 51-52.

46 Mecmûa-i İber-i İntibâh sayı 3 (Muharrem 1280 / Haziran-Temmuz 1863): 87-91.

47 Mecmûa-i İber-i İntibâh say1 4 (Rebiülâhir 1280 / Eylül-Ekim 1863): 113-120. 
Arapça eserden İlm-i Tabakatü'l-Arz adıyla 1853 yılında İstanbul'da yaptığı çeviridir. Arapça eser de gerçekte Nérée Boubée'nin Géologie populaire à la Portée de Tout le Monde appliquée à l'Agriculture et à l'Industrie (Paris, 1833) adlı kitabının Mısır'da 1842'de bir heyetçe yapılan tercümesinden başka bir şey değildir. ${ }^{48}$ Makalenin yazarı Kaymakam Abdülhalik enNasûhî Bey (1836-1912), Yunanca "Yere dair söz" (el-kelâm fi'l-Arz) anlamına geldiğini belirttiği jeolojinin son asrın çok faydalı yeni bir bilim olduğuna işaret ettikten sonra, bu bilimin Türkçe'de ilm-i tabakatu'l-arz şeklinde adlandırılmasını eleştirmektedir: “İlmu Tabakati'l-Arz adiyla işbu ilimden bir kitâb dahî Arabîden Türkceye tercüme ve tab olunmuş ise de bu fenne tabakatu'l-arz tesmiyesi pek yolunda değildir." Böylelikle, hem Rusçuklu esSeyd Mehmed Ali Fethi'nin söz konusu çevirisinden söz etmekte, hem de "jeoloji” teriminin “ilm-i tabakati'l-arz" deyimiyle karşılanmasına itiraz etmektedir. Çünkü ona göre bu bilim, yerin sadece katmanlarını değil geçirdiği değişim ve felaketlerle hangi biçimler alıp nasıl oluştuğunun tarihini de araştırmaktadır. Ayrıca yazar, coğrafya ve jeoloji bilimleri ile bunların tarihlerini iyice öğretmek için Tevârîhu'l-Ulum adlı kendi yazdığg bir kitaba işaret etmektedir. Ancak “bir müddetdir tertîb ve te'liffine muvâzıb bulundığım” ifadesinden söz konusu kitabın yayınlanıp yayınlanmadığı anlaşılamamaktadır. ${ }^{49}$ Yayınlanmışsa, modern bilim tarihine ilişkin Türkçe kaleme alınmış erken ve ilginç bir örnekle karşı karşıyayız demektir. ${ }^{50}$

Dergide coğrafya ile ilgili diğer iki makaleden biri "Bir Zâtın Eseri" imzasılla yayınlanan “Coğrafya İlmine ve Taksîmine Dâ'ir Malûmât” başlıklı yazıdır. Yazıda önce coğrafya kelimesinin etimolojisi, bu kelimenin Yunanca bir kelimenin Arapçalaşmış şekli olduğu, astronomi ile ilişkisi, özellikle matematiksel coğrafya veya kozmografya denilen bölümü nedeniyle astronomi ile aynı bilim zannedildiği fakat her ikisinin ayrı bilimler olduğu ifade edilmektedir. Ardından coğrafyanın doğal (tabîiye), dinsel (diniye), edebî (edebiye), tarihsel (tarîhiye), siyasî (siyâsiye), sahibine "politikacı" denilen politik (politikiye) adı verilen dalları olduğu, ancak günümüzde hepsinin Avrupalılarca "coğrafya" adı altında makbul ve meşhur bir bilim olarak görüldüğü söylenmektedir. ${ }^{51}$ İkincisi ise "Mektûbî Hâriciye Hulefâsından

48 Celal Şengör, “Osmanlı'nın İlk Jeoloji Kitabı ve Osmanlı'da Jeolojinin Durumu Hakkında Öğrettikleri,” Osmanlı Bilimi Araştırmaları 11, 1-2 (2009-10): 119-158.

49 Mecmûa-i İber-i İtibâh sayı 8 (Muharrem 1281 / Haziran-Temmuz 1864).

50 Öte yandan, Jale Baysal, Osmanlı Türklerinin Bastıkları Kitaplar 1729-1875, haz. Hasan S. Keseroğlu ve İlkim Mengülerek (İstanbul: Hiperlink, 2010)'da böyle bir yazara ve esere rastlanmamaktadır. Ayrıca, biyografisinde Arapça, Fransızca, Almanca, İtalyanca okuyup anlardı denilen Abdulhalik Nasuhi'nin sadece Volney'1n (17571820) Tedmür Harabeleri adlı eserini tercüme ettiği fakat bunun da elde olmadığı belirtilmektedir. Bkz. İsmail Hakkı Aksolak, "Nâsûhî Abdülhâlik," Türk Edebiyatı Isimler Sözlüğü (TEİS), erişim tarihi: 18.08.2021, http:// teis.yesevi.edu.tr/madde-detay/nasuhi-abdulhalik.

51 Metinde birlikte kullanılan "coğrafya-i siyâsiye" ve "coğrafya-i politikiye” ile ilgili açılamalar şöyledir: “... ve ahkâm ve siyâset ve tedbîre müteallik olana (coğrafya-i siyâsiye) tesmiye olunub imdi bu me'âlde temkîn-i şevket ve saltanat ve temhîd-i ahkâm ve siyâset ve tevcîh ve taksîm-i memleket ve sulh ve harbde hîle ve mekr-i 'aduvvdan hıfz u hırâset ve gayr-1 zalik umûr-1 devletde hüsn-i idâre ve basirete (coğrafya-i politikiye) 1tlâk1 vukû' bu 'asrlarda mutlaka mekr ve müdâheneye (politika) ve sâhibine (politikacı) ta 'bîri şuyû' bulmuşdur'. Mecmûa-i İbretnümâ sayı 10 (Receb 1282 / Kasım-Aralık 1865): 41-43. 
Saîd" imzasıyla kaleme alınan ve denizlerdeki gelgitleri anlatan "Medd ü Cezr-i Bihâr" adlı makaledir. Makalede bir doğa olayı olarak tanımlanan iç ve dış denizlerdeki gelgitlerin geometrik (hendesî) ve fiziksel (hikemî) kanıtlaması, genel çekim gücü (kuvve-i câzibe-i umûmiye), Ay’ın çekim gücü (kuvve-i câzibe-i Kameriye), Dünya'nın çekim gücü (câzibe-i Arz), Güneş'in çekim gücü (Şemsin kuvve-i câzibesi) kavramları kullanılarak ayrıntılı şekilde açıklanmaktadır. Ayrıca gelgitlerin şiddetinde bu nedenlerin yanı sıra dalgaların şiddetinin, sahillerin şeklinin, derinliğin, rüzgâr muhalefetinin, nehirlerin denize akış yerlerinin de etkili olduğu belirtilerek sahillere yapılacak kale, liman, rıhtım inşaatlarında ve gemilerin limanlara çekilmesinde gelgitlerin yüksekliğinin dikkate alınması gerektiği hatırlatılmaktadır. Yazıda, sözgelimi "mîlâddan üç yüz sene evvel yaşayan Font", "hükemâ-yı Yunandan Felin'âs" gibi bazı isimlerle kimin kastedildiği anlaşılamasa da konunun tarihi hakkında bilgi verilmektedir. Burada konuyla uğraşan ve birbirine zit açıklamalar yapan Kepler (1571-1630) ve Galilei'den (1564-1642) söz edilmezken Descartes’ın (1595-1650) gelgitler hakkında boş sözler ve deliller ortaya attığı halde tartışma sanatındaki üstünlüğü dolayısıyla görüşlerini dönemin bilginlerine kabul ettirdiği şeklindeki tuhaf açıklamalar dikkati çekmektedir. ${ }^{52}$

"Hıfz-1 Sıhhat" başlıklı başka bir yazının da yine "Bir Zât Cânibinden" imzasını taşıdığı görülmektedir. İki bölümlük yazının konusu, tıp alanındaki batıl inançlara, hatâlı uygulamalara ve anlayışlara yönelik bilindik eleştiri ve uyarılardan ibarettir. Yazının girişindeki temiz ruhlu, deneyimli, yetkin ve seçkin kişilerin dualarının iyileştirici etkisinin olabildiği fakat buna nadiren görüldüğü ifadesi dikkat çekmektedir. ${ }^{53}$ Yazıdan ayrıca, o dönemde Karadeniz kıyısındaki Yedi Kumlar adı verilen yerin kum tedavisi için kullanıldığını, Çamlıca'nın da İstanbul'un gözde bir mesire yeri olduğunu öğreniyoruz. ${ }^{54}$

Mahmûd Celâl Bey imzalı "Elmâsa Dâir Malûmât” başlıklı madencilikle ilişkilendirilebilir yazının adı açıklanmayan bir dergiden alındığ yerdir" denilen Hindistan, Brezilya ve Rusya'daki madenlerden, işçilerin çıkardıkları elmasları çalmamaları için çırılçıplak çalıştırıldıklarından ayrıca tedbiren her işçinin başına bir adam dikilmesine rağmen yutarak hırsızlık yaptıklarından söz edilmektedir. Hatta doksan beş kırat gelen elmasların çıkarıldığı Brezilya'daki madenlerde çalışan zencilere (siyâh Arablar) yetmiş buğdây ağırlığında elmas çıkardıklarında özgürlükleri verilmesine karşın kabul etmeyip yutarak çalmak için çalışmaya devam ettikleri şeklinde ilgi çekici anlatımlar görülmektedir. Ayrıca pırlanta, felemenk, roza ve hindkârî şeklinde dört çeşidinden en değerlisinin ilki, en niteliksizinin sonuncusu olduğu, hangi tarihte işletilmeye başlandığının bilinmediği, Kardinal Mazarin'in (1602-1661) XIV. Louis'ye hediye ettiği ve onun adiyla [La Grand Mazarin] anılan ve on iki parçadan ibaret pırlantadan bahsedilmektedir. ${ }^{55}$ İkinci

52 Mecmûa-i İbretnümâ sayı 16 (Muharrem 1283 / Mayıs-Haziran 1866): 24-31.

53 Mecmûa-i İber-i İntibâh sayı 3 (Muharrem 1280 / Haziran-Temmuz 1863): 81-87.

54 Mecmûa-i İber-i İntibâh say1 4 (Rebiülâhir 1280 / Eylül-Ekim 1863): 99-105.

55 Mecmûa-i İbretnümâ sayı 12 (Ramazan 1282 / Ocak-Şubat 1866): 27-31. 
bölümde elmasın nasıl ve hangi aletle işlendiği, nasıl oluştuğu, ölçü biriminin kırat olduğu, dört buğdaya denk geldiği, çıkarılmasının çok masraflı olduğu, değerini kesimi (kıta), parlaklık ve temizliğinin belirlediği, kusurlu olanlarının yok edildiği, Dünyadaki ünlü elmasların kimlerde bulunduğu, kıratları ve değerleri gibi konulardan söz edilmektedir. Elmasın nasıl oluştuğu anlatılırken eskilerin bunu bilmediği, Newton’un (1643-1727) kömür cinsinden olduğunu söylediği ve Lavoisier'in (1743-1794) de yakılınca kömüre dönüştüğünü deneylerle gösterdiği ifadeleri dikkati çekmektedir. Yine Dünya'daki meşhur değerli elmaslardan söz edilirken Târîh-i Raşid'e dayandırılarak Eğrikapı mezbelesinde bir derbederce bulunup birkaç el değişimi sonunda saray tarafından alınarak padişah hazinesine giren Kaşıkçı Elması'nın hikâyesi anlatılmaktadır. Tefrika, eski bir mecmuadan alınıp aynen aktarılan bu makalenin sıhhatine derginin kefil olamayacağı notuyla sona ermektedir. ${ }^{56}$

Astronomiye ilişkin "Kaymakam Hamdi" tarafından yazılan "İlm-i Hey’et” başlıklı makale, astronomiyi, gökcisimlerinin durum ve hareketlerinin bilimi olarak tanımlar. Astronomiyi dört büyük kısma ayırır: Kurucusunun Batlamyus (85-165) olduğu küresel astronomi (hey'et-i küreviye); uygulamalı astronomi (hey'et-i amelî); kurucusunun Kopernik (1473-1543) olduğu kuramsal astronomi (hey'et-i nazariye) ve Newton'un kurduğu belirtilen doğal astronomi (hey'et-i tabîtye). Buna göre matematiksel coğrafya, takvim ve saat yapımı gibi pek çok uygulaması olan astronomi, insan aklının ürettiği bilimlerin en gelişmişi ve üstünüdür. Öğrenimi için, matematiksel bilimlere (ulûm-ı riyâziye), mekanik bilimine (ilm-i cerr-i eskâl), optik (zîyâ ve basar ilmi), fizik (hikmet-i tabî̂ye) ve meteoroloji (alâim-i semâviye) bilimlerine aşina olmak gerekir. ${ }^{57}$ Hatta bazı sonuçlarının anlatımı görselliği gerektirdiğinden, bu bilim ile uğraşanların resim sanatıyla bile ilgisi olmaları gerekir. Astronominin bu alanlara ihtiyacı fark edilemediğinden İskenderiye Okulu'ndan (İskender Mektebi) Tycho Brahe (1546-1601) ve Kepler (1571-1630) zamanına dek, alanındaki ilgisiz konular uzaklaştırılamamış ancak yakın zamanda konuları tam olarak belirlenip düzgün rasathaneler kurulabilmiş ve gelişebilmiştir. Yazar, eski astronominin astrolojiye (ilm-i nücûm) dayandığını ve yıldızların etkisine inanmanın çürüklüğünün gün ortasında görünen Güneş (ke'ş-Şems fî vasati'n-nehâr) kadar bariz olduğunu vurgulamaktadır. Eski astronomi bazı ünlü Arap bilginler ve Timur'un torunu Uluğ Bey (1394-1449) tarafindan hayli ilerletilmişse de bu alanda teleskopun (dûrbîn) icadı nedeniyle son otuz kırk senedeki gelişmeler önceki üç yüz yıldan, bu da ondan önceki üç bin yıllık dönemden çok daha fazladır. Astronomi öğreniminde matematik ve trigonometri (ilm-i müsellesât) bilmenin çok önemli olduğunu vurgulayan yazar, bu risalenin uzmanca değil sembolik anlatımlar içeren basit bir dille yazılacağını söylemekle birlikte, yazının tefrika edilen başka bölümleri yoktur. ${ }^{58}$

56 Mecmûa-i İbretnümâ, sayı 15 (Zilhicce 1282 / Nisan-Mayıs 1866): 20-28.

57 Mecmûa-i İber-i İntibâh, say1 4 (Rebiülâhir 1280 / Eylül-Ekim 1863): 106-109.

58 Mecmûa-i İber-i İntibâh sayı 5 (Şaban 1280 / Ocak-Şubat 1864): 144-147. 
Dergide matematikle ilgili iki yazıdan birincisi "Kolağası Halîl Hâlid" tarafindan başlangıç seviyesindekiler (mübtediler) için kaleme alındığı anlaşılan "İlm-i Hisâb" başlıklı makaledir. Aritmetiğin (hisâb) tanımı, sayı (aded) denilen süreksiz niceliği (kemm-i munfasıl) konu edindiği, diğerini yani "mikdâr" denilen sürekli niceliği (kemm-i muttasıl) ise geometrinin incelediği, sayıların 0'dan 9'a kadar rakamlarla gösterildiği, bu rakamların adları ve sembolleri teker teker yazılıp belirtilerek on sayı türü olduğu söylenmektedir. Bunlar hakkında tam sayı (aded-i sahîh), kesirli (kesr) sayı, tam sayılı kesir (aded-i kesr maa'l-kesr), belirli sayı (aded-i muayyen), mutlak sayı (aded-i mutlak), basit sayı (aded-i basît), bileşik sayı (aded-i mürekkeb), çift (zevc) sayı, tek (ferd) sayı ve asal sayı (aded-i aslî) sıralamasıyla açıklamalar yapılmaktadır. Yazı beş aritmetik işlem (amâlât-ı hamse-i hisâbiye) denilen sayıp numaralandırma (tadâd ve terkîm), toplama (cem), çıkarma (tarh), çarpma (darb) ve bölme (taksîm) hakkında, bu işlemlerde kullanılacak işaretler gösterilip işlemdeki sayıların adlarının ne olduğu belirtilecek şekilde basit örnekler içeren açıklamalarla sona ermektedir. ${ }^{59}$

Matematikle ilgili "Hülâsatu'l-Hisâb" başlıklı ikinci yazı, özellikle bilim tarihimiz açısından önemlidir. Adı yazıya başlık yapılan bu eser, son dönem İslâm matematikçilerinden Bahauddin Amûlı̂’ye (1547-1621) aittir. İsmi, onaltıncı yüzyılda Suriye'de bulunan Balebek'de (bugün Lübnan'daki Baalbek) doğduğu zannedilerek yanlış olarak el-Âmilî şeklinde yazılıp tanınan el-Âmulî’nin, tefsîr ve edebiyatın yanı sıra astronomi ve matematiğe ait eserleri vardır. Bunlardan en fazla şöhret bulanı söz konusu eser olduğu için yazar "Sâhib-i Hülâsa" adıyla anılmıştır. Birçok şerhi olan eser, Doğu medreselerinde çok fazla rağbet görmüş ${ }^{60}$ ve on yedinci yüzyıldan itibaren Osmanlı medreselerinde üç yüzyıl boyunca matematik eğitiminde ders kitabı olarak kullanılmıştır. Eserin Türkçe’ye ilk ve tek tercümesinin Nihâyetu'l-İdrâk fì Tercümet Hülâsati'l-Hisâb adıyla Kuyucaklızâde (öl. 184647) tarafından yapıldığı bilinmektedir. ${ }^{61}$ Oysa şimdi Mecmûa-i İber-i İntibâh'ın dördüncü sayısındaki "Hülâsat'l-Hisâb” başlıklı yazıda Muhammed Bahauddin'e ait olduğu ve pek çok inceliğin yanı sıra aritmetik ve cebre ilişkin yazarın dönemine kadar keşfedilmiş ilkeleri içerdiği söylenip "Lisân-ı Türkîye tahvîl ve min gayr-i haddin bazı nüktelerin şerh ve tafsîl olunacağı" söylenmektedir. Bir giriş (mukaddime) ve on bölümden (bâb) oluştuğu bildirilen bu eserin mütercimi olarak "Erkân-ı Harb Kolağası Vidinli Tevfîk"in yani döneminde "Osmânl riyâziyûnunun bihakkın reîsi" sayılan ${ }^{62}$ ünlü Vidinli Hüseyin Tevfik Paşa'nın (1832-1901) adı görülmektedir. Bununla birlikte Mecmûa-i İber-i İtibâh'ın dördüncü sayısı dışında tercümenin tefrikalarına rastlanmamaktadır. Başlanıldığı açık olan böyle bir

59 Mecmûa-i İber-i İntibâh sayı 4 (Rebiülâhir 1280 / Eylül-Ekim 1863): 121-126.

60 Salih Zeki, Âsâr-ı Bâkiye, c. 3, haz. Melek Dosay Gökdoğan Remzi Demir ve Mutlu Kılıç (Ankara: Babil, 2004), 199-201.

61 Ekmeleddin İhsanoğlu, “Osmanlı Bilimi Literatürü,” Osmanlı Medeniyeti Tarihi, c.2 (İstanbul: IRCICA, 1999) içinde, 436.

62 Bursalı Mehmed Tahir, Osmanlı Müellifleri, c.3, haz. Mustafa Tatc1 ve Cemâl Kurnaz (Ankara: Bizim Büro, 2000), 258. 
tercümenin akıbeti meçhuldür. Vidinli Tevfik'in matematik eserleri içinde böyle bir tercümesi görülmemektedir. ${ }^{63}$ Yaklaşık dört yıl sonra Cemiyet-i Tedrisiye-i İslâmiye'nin eseri olarak çıkarılan Osmanlının ilk Türkçe matematik dergisinin yazar kadrosu içinde yer alıp dergideki "ekserî makâlâtın sâhibi” olduğu için “Vidinli’nin dergisi” sayılabilecek Mebâhis-i İlmiye' de (1867-1869) de böyle bir çalışmasına rastlanmamaktadır. ${ }^{64}$

Tercümeye gelince, burada önce Balebek'de doğduğu söylenen yazarın hayatı hakkında kısaca bilgi verilip eserin çok kısa olan Arapça besmele hamdele ve salvelesi aynen aktarılarak "Mukaddime" başlığıyla çeviriye başlanmaktadır. "İlm-i hisâb"ın tanımının ardından sayı ya "mutlak" ki bu durumda "aded-i sahîh" adını alır ya da "kesr" olarak ikiye ayrılır denilerek "mutlak" sayının da tekrar rasyonel (muntak) ve irrasyonel (asamm) olarak ikiye ayrıldığından bahsedilmektedir. Yedi sayfalık tefrikanın büyük kısmının, Vidinli Tevfîk’in tanım da dâhil olmak üzere bu kavramları açıklamaya yönelik dört uzun dipnotundan (hâşiye) ibaret olduğu görülüyor. Akıbeti belirsiz tercümenin dördüncü dipnotunun sonunda Vidinli Tevfîk'in ünlü matematikçi Fermat'dan (1601-1665) söz etmesi ve onun $2^{x}+1$ formülünün (düstûr) $x=32$ için elde edilen 4294967297 sayısı 641 ile bölünebildiği için doğru olmadığını söylemesi dikkat çekmektedir. ${ }^{65}$

\section{Sonuç}

Bilindiği üzere Osmanlının ilk popüler bilim dergisi, Haziran 1862'de çıkan Местиa-i Fünûn'dur. Osmanlıdaki ikinci popüler bilim dergisinin ise, Aralık 1862'de Cemiyet-i Kitâbet'ın yayın organı olarak önce Mecmûa-i İber-i İntibâh ardından Mecmûa-i İbretnümâ adıyla yayımlanan dergi olduğu anlaşılmaktadır. Dergi, Aralık 1862-Haziran 1864 yıllarını kapsayan dönemde sekiz sayı yayınlandıktan sonra Ekim 1865 'e kadar yayınına ara vermiş ve bu tarihten Mayıs 1866'ya kadar yeni adıyla düzenli olarak her ay çıkarılmıştır. Anılan tarihler arasındaki yaklaşık üç buçuk yıl boyunca derginin toplam on altı sayısı yayınlanmıştır. Derginin amacının, eğitim öğretimin önemine binaen, öncelikle okul çocuklarının yararlanacağı bir kaynak eser oluşturmak olduğu ancak derginin bayilerde de satışa çıkarıldığı ifade edilmektedir.

Çeşitli manzûm ve mensûr türleriyle edebiyat ve tarihe ilişkin yazıların çokluğuna rağmen dergide sağlık, denizcilik, coğrafya, astronomi, matematik bilimleri hatta çiçek

63 Ekmeleddin İhsanoğlu, Ramazan Şeşen ve Cevat İzgi (haz.). Osmanlı Matematik Literatürü, c. 2, (İstanbul: IRCICA, 1999), 401-404.

64 Feza Günergun, "Matematiksel Bilimlerde İlk Türkçe Dergi: Mebâhis-i İlmiye (1867-69)," Osmanlı Bilimi Araştırmaları 8, 2 (2007): 1-42. Vidinli Tevfik'in biyografisinde, kolağalı̆ı̆ rütbesini daha yeni almış olan Paşa'nın, bu tercüme-tefrikanın yayınlandığı sırada, iki yıl için Paris'e askeri ateşe olarak gönderildiği yazılmaktadır. Bkz. Atilla Polat, "Son Dönem Osmanlı Matematikçi-Bürokratı Vidinli Hüseyin Tevfik Paşa'nın Hayatı," Osmanlı Bilimi Araştırmaları 20, 1 (2020): 22. Mecmuâ-i İber-i İntibâh'ın Rebiülâhir 1280 (Eylül/Ekim 1863) tarihli dördüncü sayısında başlanan bu tefrikanın devam edememesinin nedeni belki de iki yıl sürecek bu Fransa yolculuğudur.

65 Mecmûa-i İber-i İntibâh sayı 4 (Rebiülâhir 1280 / Eylül-Ekim 1863): 127-134. 
yetiştirme, süngercilik ve sünger ticareti gibi farklı alanlara ilişkin yazı ve resimler bulunduğu görülmektedir. Bazı yazıları ve basılan kitap haberleriyle yer yer dönemin kültür hayatına yönelik dikkat çekici bilgiler de içeren derginin en ilginç yönlerinden birisinin, gerçekte bir "uyanış" ya da "uyanışa götürme yolu” yani bir tür "renaissance" anlamına gelen iddialı fakat alışıldık ya da süreli bir yayın için hiç de uygun olmayan adı üzerinden getirdiği eleştiriler nedeniyle Местиа-i Fünûn ile girdiği polemik olduğu söylenebilir. Bununla birlikte, Osmanlının yayın sırası bakımından bir ve iki numaralı popüler bilimsel dergileri arasındaki bu polemiğin, bilimsel olmayıp, birbirlerinin değer ve itibarlarına yönelik olduğu görülmektedir. Öte yandan “uyanış”tan söz eden iddialı adına karşın “Arapça ve Farsça cennet dilidir, Farsça dördüncü kat gökteki meleklerin dilidir, Arapça'dan sonra Dünya'nın en güzel dili Farsça'dır, azbu'l-beyân Arabî' gibi ifadeleri, ve mikroskop ve hücre teorisinden yoksun Orta Çăg' da İslam Dünyası'nda kaleme alınan zooloji ve botanik eserlerinin bu alanda döneminde Batı'da yazılan eserlerle kıyaslayıp üstünlüğünü iddia eden değerlendirmeleri nedeniyle, Cemiyet-i Kitâbet ve dergisi Mecmûa-i İber-i İntibâh / Mecmûa-i İbretnümâ'nın geleneksel bir zihniyet çizgisinde bulunduğu düşünülebilir.

Nihayet derginin bilim ve kültür tarihimiz bakımından belki en kayda değer yönlerinin, doğrudan Mukaddime'den iktibaslarla oluşan yazılar nedeniyle on dokuzuncu yüzyıl Osmanlı düşünce hayatında İbn Haldun’un etkisini gösteren örnekler içermesi; bibliyografik kayıtlarda görülmeyen, Abdülhalik en-Nasûhî Bey tarafından kaleme alındı̆̆ı ifade edilen modern coğrafya ve jeoloji tarihine dair Tevârîhu'l-Ulûm adlı bilim tarihi eserinden söz etmesi; ve ünlü matematikçi Vidinlî Tevfîk' in başladığı fakat akıbeti bilinmeyen el-Âmulî’nin Hülâsatu'l- Hisâb tercümesinin yedi sayfasının yayınlamış olması söylenebilir.

Hakem Değerlendirmesi: Dış bağımsız.

Çıkar Çatışması: Yazar çıkar çatışması bildirmemiştir.

Finansal Destek: Yazar bu çalışma için finansal destek almadığını beyan etmiştir.

Peer-review: Externally peer-reviewed.

Conflict of Interest: The author has no conflict of interest to declare.

Grant Support: The author declared that this study has received no financial support.

\section{KAYNAKÇA / BIBLIOGRAPHY}

\section{Basılı kaynaklar / Printed sources}

Baysal, Jale. Osmanlı Türklerinin Bastıkları Kitaplar 1729-1875. Hazırlayanlar: Hasan S. Keseroğlu ve İlkim Mengülerek. İstanbul: Hiperlink, 2010.

Berkes, Niyazi. Türkiye’de Çağdaşlaşma. Hazırlayan Ahmet Kuyaş. İstanbul: Yapı Kredi Yayınları, 2002.

Beyoğlu, Süleyman. "Kamil Paşa, Yusuf." TDV İslâm Ansiklopedisi. 24: 283-284. Ankara: Türkiye Diyanet Vakfi, 2001.

Bursalı Mehmed Tahir. Osmanlı Müellifleri I-II-III. Hazırlayanlar: Mustafa Tatcı ve Cemâl Kurnaz. Ankara: Bizim Büro, 2000.

Çavdar, Necati. "Rothschildler ve Osmanlı İmparatorluğu.” Sezai Balcı ve Mustafa Balcıŏlu'nun Rothschchildler 
ve Osmanlı İmparatorluğu adlı eserinin incelemesi. Gaziosmanpaşa Üniversitesi Sosyal Bilimler Araştırmaları Dergisi 12, 2 (2017): 267-271.

Demirhan, Ayşegül. Klsa Tıp Tarihi. Bursa: Bursa Üniversitesi Yayınevi, 1982.

Günergun, Feza. "Matematiksel Bilimlerde İlk Türkçe Dergi: Mebâhis-i İlmiye (1867-69)." Osmanlı Bilimi Araştırmaları 8, 2 (2007): 1-42.

Günergun, Feza ve Asuman Baytop. "Hekimbaşı Salih Efendi (1816-1895) ve Botanikle İlgili Yayınları.” Osmanlı Bilimi Araştırmaları 2 (1998): 293-317.

Günergun, Feza, Şeref Etker ve Abdullah Köşe, “Zeynep-Kamil Hastanesi’nin Kuruluşu ve Vakfiyesi,” Osmanlı Bilimi Araştırmalart 5, 2 (2004): 1-37.

İbn Haldun. Mukaddime 1-II. Hazırlayan: Süleyman Uludağ. İstanbul: Dergâh Yayınları, 2004.

İhsanoğlu, Ekmeleddin, Ramazan Şeşen ve Cevat İzgi (hazırlayanlar). Osmanlı Matematik Literatürü, c.2. İstanbul: IRCICA, 1999.

İhsanoğlu, Ekmeleddin. "Osmanlı Bilimi Literatürü.” Osmanlı Medeniyeti Tarihi, c.2, editör Ekmeleddin İhsanoğlu içinde, 363-435. İstanbul: IRCICA, 1999.

Mecmûa-i Fünûn, sayı 8, Şabân 1279 (Ocak/Şubat 1863); sayı 9, Ramazan 1279 (Şubat/Mart 1863); sayı 13, Muharrem 1280 (Haziran/Temmuz 1863).

Mecmûa-i İber-i Intibâh, sayı 1, Receb 1279 (Aralık/Ocak 1862/1863); sayı 2, Şevvâl 1279 (Mart/Nisan 1863); say1 3, Muharrem 1280 (Haziran/Temmuz 1863); say1 4, Rebiülâhir 1280 (Eylül/Ekim 1863); sayı 5, Şaban 1280 (Ocak/Şubat 1864); sayı 6, Ramazan 1280 (Şubat/Mart 1864); sayı 7, Şevvâl 1280 (Mart/Nisan 1864); say1 8, Muharrem 1281 (Haziran/Temmuz 1864).

Mecmûa-i İbretnümâ, say1 9, Cemaziyelâhir 1282 (Ekim/Kasım 1865); sayı 10, Receb 1282 (Kasım/Aralık 1865); say1 11, Şaban 1282 (Aralık/Ocak 1865/1866); say1 12, Ramazan 1282 (Ocak/Şubat 1866); say1 13, Şevvâl 1282 (Şubat/Mart 1866); sayı 14, Zilkade, 1282 (Mart/Nisan 1866); say1 15, Zilhicce 1282 (Nisan/Mayıs 1866); sayı 16, Muharrem 1283 (Mayıs/Haziran 1866).

Polat, Atilla. "Son Dönem Osmanlı Matematikçi-Bürokratı Vidinli Hüseyin Tevfik Paşa'nın Hayatı." Osmanlı Bilimi Araştırmaları 20, 1 (2020): 16-46.

Salih Zeki. Âsâr-ı Bâkiye, c.3. Hazırlayanlar Melek Dosay Gökdoğan, Remzi Demir ve Mutlu Kılıç. Ankara: Babil, 2004.

Sena, Cemil. Filozoflar Ansiklopedisi I. İstanbul: Remzi Kitabevi, 1974.

Şengör, Celâl. “Osmanlı'nın İlk Jeoloji Kitabı ve Osmanlı’da Jeolojinin Durumu Hakkında Öğrettikleri.” Osmanlı Bilimi Araştırmaları 11, 1-2 (2009-10): 119-158.

Tanpınar, Ahmed Hamdi. 19'uncu Asır Türk Edebiyat Tarihi. İstanbul: Çağlayan Kitabevi, 2003.

Ulusoy, Nalcıŏlu Belkıs. "Türkçe Dergiciliğinin Sancılı Başlangıcı.” Dergicilik Üzerine, editör: Aslı Yapar Gönenç, içinde 7-39. İstanbul: Koyu Kitap, 2013.

Ülken, Hilmi Ziya. Türkiye'de Çağdaş Düşünce Tarihi. İstanbul: Ülken Yayınları, 2005.

\section{Elektronik kaynaklar / Electronic sources}

Aksolak, İsmail Hakk1. "Nâsûhî Abdülhâlik,” Türk Edebiyatı İsimler Sözlüğ̈̈ (TEİS). Erişim 18.08.2021, http://teis. yesevi.edu.tr/madde-detay/nasuhi-abdulhalik.

Aslan, Mehmet. “Ali Haydar Bey Mihalıçl1”, Türk Edebiyatı Ísimler Sözlügü (TEİS). Erişim 17.08.2021. http://teis. yesevi.edu.tr/madde-detay/ali-haydar-bey-mihalicli.

Arslan, Mehmet. "Fâzıl Bey," Türk Edebiyatı İsimler Sözlüğü (TEISS). Erişim 18.08.2021. http://teis.yesevi.edu.tr/ madde-detay/fazil-pasa.

Arslan, Mehmet. "Subhi, Hasan Subhi," Türk Edebiyatı Ísimler Sözlüğ̈̈ (TEİS). Erişim 18.08.2021. http://teis. yesevi.edu.tr/madde-detay/subhi-hasan-subhi. 
